\title{
1 Review
}

\section{Pharmacological autophagy regulators as therapeutic agents for 3 inflammatory bowel diseases}

\section{Sruthi Vijaya Retnakumar ${ }^{1}$ and Sylviane Muller ${ }^{1,2, *}$}

6

7

${ }^{1}$ CNRS-University of Strasbourg, Biotechnology and cell signaling, Institut de science et d'ingénierie supramoléculaire, 67000 Strasbourg, France

${ }^{2}$ University of Strasbourg Institute for Advanced Study, 67000 Strasbourg, France.

*Correspondence:

sylviane.muller@unistra.fr (S. Muller)

Keywords: animal models; autoinflammatory diseases; autophagy; Crohn's disease; inflammatory bowel diseases; therapeutic antibodies; therapeutic peptides; ulcerative colitis

\section{Abstract:}

The arsenal of effective molecules to treat patients with chronic inflammatory bowel diseases (IBDs) remains limited. These remitting-relapsing diseases have become a global health issue and new therapeutic strategies are eagerly awaited to regulate the course of these disorders. Since the association between autophagy-related gene polymorphism and an increased risk of Crohn's disease development has been discovered, a new domain of investigation has emerged, focused on the intracellular degradation system, with the objective to generate new medicines that are safer and more targeted. This review summarizes the drugs administrated to IBDs patients and describes recently emerged therapeutic agents; we compile evidence on the contribution of autophagy to IBDs pathogenesis, give an overview of pharmacological autophagy regulators in animal models of colitis, and propose novel therapeutic avenues based on autophagy components. 

environmental, genetic, microbial, and immunological factors

Inflammatory bowel diseases (IBDs) have an increased incidence in developed countries, affecting $0.1 \%$ of the western population. They adversely affect several million people worldwide, with the highest rate of incidence in Europe and North America, probably as a result of diet, lifestyle, and sanitation [1-3]. IBDs, which cause inflammation of the lining of the digestive tract, are commonly detected in young people at the age of 18-25 years, and so far, they are non-curable [4]. The patients complain of frequent and chronically relapsing flares, which can lead to abdominal pain, diarrhea, rectal bleeding, fatigue, malnutrition, and weight loss. The major entities of IBDs are typified by Crohn's disease (CD) and ulcerative colitis (UC). Though both share several clinical symptoms, CD and UC have markedly distinct features concerning their pathology and origin [5-7]. CD can affect any part of the gastrointestinal tract most commonly in terminal ileum and colon, and can involve all layers of intestinal tissues. UC affects the large intestine only, and the inflammation is restricted to the mucosal layer [8]. CD and UC are associated with increased intestinal permeability, which involves paracellular passage regulated through tight junctions (TJs) $[3,9]$. Single nucleotide polymorphisms located in genes encoding interacting $\mathrm{TJ}$ proteins and changes in the expression of some TJ proteins have been described [10-14]. Interestingly, several studies have shown the role of autophagy (Box 1) in the defects observed in intestinal TJ barriers that occur in IBDs [15].

The etiology of IBDs involves complex genetic factors and environmental elements. Genome-wide association studies identified more than 200 confirmed genetic risk loci associated with this set of diseases. These loci are notably involved in common, albeit central, cellular pathways, such as autophagy, cytokine signalling, intestinal barrier regulation, and microbial recognition [16-18]. Recent studies hypothesized that IBDs result from chronic abnormal immune responses against enteric bacteria or gut flora that develop in genetically susceptible individuals. IBDs are therefore both a consequence of autoimmune and immune-mediated phenomena. Autoreactive antibodies (Abs) and autoreactive T cells co-exist with cytotoxic leukocytes for colonic epithelial cells and serum Abs against colonic epithelium, which are cross-reactive with E. coli antigens, for example. Among the large diversity of Abs occurring in patient's serum, some may serve to differentiate various forms of IBDs and can be used as predictors for disease activity [19-21]. Abnormalities affecting 
the innate and adaptive immune system are largely reported in IBDs [6]. A particular subset of dendritic cells (DC) expressing the clusters of differentiation $11 \mathrm{~b}$ and 103 surface markers appears as a major provider of interleukin (IL)-23 during colitis development [22-25]. The closely related IL-23 and IL-12 cytokines, as well as their major downstream components, including IL-17, play important roles in the regulation of mucosal inflammation, especially in the gut. These cytokines control autophagosome formation and autophagic flux. The regulatory $\mathbf{T}$ cells (Tregs, see Glossary) compartment is also deeply impacted in IBDs, as discussed elsewhere [5,26,27].

The importance of gut microbiota is central in many vital functions of the body and is not solely directly linked to the intestinal functioning as originally thought. It comprises thousands of diverse microbial species that interact with the host in exerting decisive regulating effects linked to immune, metabolic (e.g., in the regulation of systemic glucose metabolism) and neurological functions. It is only relatively recently that the eminent role of the microbiota-gut-brain axis has emerged and that a connection between the gut microbiome and autophagy has been highlighted [28-31]. In IBDs, it is well documented that the microbial composition, diversity, and richness of microbiota is dramatically altered $[32,33]$. This microbial imbalance (known as gut dysbiosis) has been reported both at the mucosal and fecal level, and systematic studies have shown that in average, IBDs-affected patients display $25 \%$ fewer microbial genes (a reflection of microbiota) than healthy individuals [34,35].

A better knowledge of fundamental aspects involved in the loss of tolerance of immune functions affecting patients with IBDs and a fine understanding of the key elements prevailing in the tropism of organs, tissues or cells that typify these patients, remain a central challenge in our quest of adapted specific treatments and personalized medicine, which would target the causes and not only the symptoms of these complex disorders. A focus is given here on promising ways of intervention linked to autophagy defects that have emerged recently in this context. A brief overview of preclinical data raised with pharmacological autophagy regulators is given, mostly obtained in animal models of IBDs-mimicking colitis.

\section{Animal Models of Inflammatory Bowel Diseases}

It has long been recognised that the furtherance of new treatments is closely tied to the pertinence of relevant animal models. In the case of IBDs, more than 65 different animal models have been established, which can be classified as genetically engineered, congenic 
mutants, cell-transfer- or chemically-induced models [36]. This multiplicity of experimental in vivo models emphasizes the critical point that, in fact, none of them totally satisfies the pure criteria of human IBDs and that it is decisive to adopt several independent experimental animal models to demonstrate the efficacy of a newly-developed treatment or diagnostic tool, or to study IBDs mechanistically.

The first experimental induced colitis model was introduced as early as 1957 in rabbits [37]. Since then, many other genetically-modified animal models have been generated, which have largely contributed to understand the disease pathology and genetic features of IBDs. Genetically-engineered animal models of IBDs include IL-10, signal transducer and activator of transcription (STAT)3, X-box binding protein 1, IL-2R $\alpha$, IL-23R, transforming growth factor (TGF)- $\beta$, and tumor necrosis factor (TNF)- $\alpha$ knockout mice, and TNF superfamily member (SF)-15, IL-7, IL-17 and IL-23-expressing transgenic mice [23,38,39]. Transgenic CEABAC10 mice expressing human carcinoembryonic antigen-related cell adhesion molecule 6, a receptor for some E. coli strains, are also commonly exploited [40,41]. Based on manipulated mice, a major role of $\mathrm{CXCR}^{+}$mononuclear phagocytes-derived TNF-like ligand $1 \mathrm{~A}$ in driving IL-22 production by a subset of innate lymphoid cells that are central in the regulation of mucosal homeostasis has been demonstrated [39].

Some models are induced by chemicals that generate IBDs-like inflammation in the intestine of normal mice or rats. These models of acute or chronic colitis are notably based on the use of dextran sulphate sodium (DSS), trinitrobenzene sulfonic acid (TNBS), oxazalone and polyI:C. They are commercially available and are routinely used in research [42-44]. They are relatively simple to set up with an appreciable reproducibility and present many similarities with human colitis. Several adoptive transfer colitis models have also been exploited $[38,45]$. In these models, recipient animals are given an intraperitoneal injection of cells (e.g., CD45RB ${ }^{\text {high }} \mathrm{T}$ cells or $\mathrm{CD}^{2} \mathrm{~L}^{+} / \mathrm{CD} 44^{-} \mathrm{T}$ cells) or monoclonal (m) Abs (e.g., anti$\mathrm{CD} 40 \mathrm{Ab}$ ) and are then evaluated daily (as in the other models of colitis listed above) for survival, body weight, evidence of bloody stool and diarrhoea. Video endoscopy completes this follow-up, providing a daily visual assessment of the severity of colitis and eventually of a possible tracking of mucosal healing after treatment.

\section{Current Treatments of Inflammatory Bowel Diseases}

\section{First-line therapies for IBDs}


The first drugs used to treat IBDs with some efficacy were immunosuppressants such as aminosalicylates, corticosteroids, and thiopurines (Table 1, and references therein [46-72]. Sulfasalazine, an aminosalicylate, which is a class of anti-inflammatory compounds acting mainly as oxygen scavengers showed some potent effects. This discovery led to the development of a range of drugs falling in this class of compounds, such as mesalazine and others (Table 1). Corticosteroids were also found to be remarkably effective in both CD and UC. However, long-term toxicity, steroid dependency, and refractoriness to treatment occurring in some patients oblige in certain cases to discontinue the medication or restrict their usage $[48,68,70]$. Continuing research is therefore focused on the repositioning of such molecules that would have less deleterious secondary effects. This already led to the development of several molecules, especially budesonide (Entocort, Mikicort), an oral glucocorticoid, which is quickly metabolized by the liver, thereby reducing corticosteroidrelated side effects. It is used in the management of asthma, allergic rhinitis and various skin disorders, and has been extended to CD [47]. Although budesonide appears significantly less effective than conventional steroids (e.g., mesalazine) for inducing remission in active $\mathrm{CD}$, it displays fewer side effects [73]. It was not found to be effective, however, for maintaining remission at 12 months in $\mathrm{CD}$.

Other immunomodulators such as thiopurines, methotrexate, and calcineurin inhibitors were also explored alone or concomitantly with other drugs as treatment options for IBDs (Table 1). Thiopurines get incorporated into nucleotides and suppress $T$ cell function by decreasing the expression of pro-inflammatory cytokines. Methotrexate (e.g., Imeth, Novatrex, Methotrexate Bellon, Metoject) was found to be effective in steroid-dependent CD (effective for induction and maintenance of remission in $\mathrm{CD}$, but not in UC [74], while cyclosporine A and tacrolimus/FK-506 calcineurin inhibitors, which are strong immunosuppressive compounds, were found to decrease pro-inflammatory lymphokine production in UC $[63,75]$.

A recent study including a large cohort of CD patients demonstrated that co-administration of 5-aminosalicylate (5-ASA; mesalazine) and either azathioprine (AZA) or 6-mercaptopurine (6-MP) was not more effective than AZA/6-MP alone in terms of the requirement for rescue medications such as steroids and anti-TNF agents [76]. The cumulative probabilities of hospitalization and intestinal resectional surgery were similar between the groups of patients on either regimen. Thus, though these molecules and peptides were often effective as primary or first-line therapy for IBDs, their long-term use is severely marred by serious ailments such as myelosuppression, multiple infections, pancreatitis, and in some cases sensorineural 
hearing loss and tinnitus (Table 1), justifying the introduction of much more selective therapeutic strategies.

\section{The era of therapeutic antibodies and cell modulators for treating IBDs}

A number of Abs have been developed against cytokines and adhesion molecules, which are key players in the pathogenesis of IBDs (Table 1; Figure 1). In patients with IBDs, cytokines produced by intestinal mucosa largely contribute to the activation and migration of inflammatory cells such as monocytes and neutrophils [5-7,16]. Cytokines were therefore especially targeted for treating IBDs patients.

\section{Anti-TNF Antibodies}

The use of anti-TNF drugs (Box 2) has been a real breakthrough progress in the treatment of IBDs $[7,68,77,78]$. Several anti-TNF- $\alpha$ Abs are currently approved for treating patients with IBDs. In the case of $\mathrm{CD}$, these include infliximab (Remicade), which is a chimeric human/mouse $\mathrm{Ab}$ (and its biosimilars Inflectra, Remsisma and Flixabi), adalimumab (Humira), a fully human IgG1 mAb (and its biosimilars Mylan's Hulio, Boehringer Ingelheim's Cyltezo, Samsung Bioepis's Imraldi, Sandoz's Hyrimoz and Amgen's Amgevita), and certolizumab pegol (Cimzia), a humanized antigen-binding fragment (Fab') of a mAb that has been conjugated to polyethylene glycol. For UC, these are infliximab, adalimumab and golimumab (Simponi), a fully human IgG mAb (Table 1). A recent study has demonstrated the efficacy of golimumab in anti-TNF refractory CD patients [79]. At this stage, however, further studies are awaited in $\mathrm{CD}$ to formally assess the efficacy of golimumab in a randomized controlled trial and to establish the optimal dosing regimen.

Altogether, TNF-targeting Abs have been claimed to induce a clinical response in about $60 \%$ of $\mathrm{CD}$ and UC patients, a result that is remarkable in the context of these severe and heterogenous diseases $[50,62,77]$. It is however important to remind the well-characterized serious adverse effects (SAEs) induced in certain patients by TNF blockers when given for long periods of treatment. Two major concerns with these drugs include the risk of serious infections and malignacies [80-83].

\section{Non-anti-TNF biological therapies}

Apart from TNF- $\alpha$, other cytokines are also used as targets in emerging therapeutic strategies [84]. Ustekinumab (Stelara) is a human IgG1 mAb that targets the p14 subunit of IL-12 and IL-23 by inhibiting their binding to their receptors (Table 1; Figure 1). This mAb, which has 
been approved by the American Food and Drug Administration (FDA) in 2016, showed efficacy in $\mathrm{CD}$ patients with moderately-to-active disease.

Other biologics are currently evaluated for their potential efficacy. It is the case, for example, of risankizumab (BI-655066 or ABBV-066), brazikumab (AMG 139 or MEDI2070), briakinumab (ABT-874), mirikizumab (LY3074828) which are other Abs that target IL-23 by binding to its P19 subunit (Figure 1; Table 2)[85-94] [72,95-103].

Briakinumab is a human mAb that was initially developed for treating rheumatoid arthritis (RA), MS, and IBDs. In November 2009, completion of a phase-III clinical trial for plaque psoriasis and a phase II clinical trial for MS was announced. A Phase-II clinical trial for CD was underway [104]. Head-to-head comparisons were made with regard to etanercept (Enbrel), a dimeric fusion protein targeting TNF, and placebo, in double-blind trials. The results gained with briakinumab were promising in psoriasis $(81-82 \%$ of patients under briakinumab, 40-56\% under etanercept, and 7\% under placebo reached Psoriasis Area Severity Index reduction of at least $75 \%$ ). On January 2011, the withdrawal of briakinumab application was announced to favour other strategies.

Migration of leukocytes to mucosal lesions is important in the pathogenesis of IBDs, and this trafficking process is actively mediated by integrins. Hence, targeting integrins has emerged as another way for potential therapy. The first attempt in this area was based on natalizumab (Tysabri), a human IgG4 Ab targeting the $\alpha 4$ integrin subunit (Table 1). Its use, however, was preferable for short-term treatment. In some rare cases, due to inhibition of leukocyte migration into central nervous system, it was found to promote reactivation of John Cunningham virus in the brain, resulting in the development of progressive multifocal leukoencephalopathy (PML), a SAE that precluded its indication.

Vedolizumab (Entyvio) is an IgG1 mAb, which also blocks the $\alpha 4 \beta 7$ integrin subunit but thanks to its gut selectivity, it was not associated with PML (Table 1). In phase-III clinical trials, vedolizumab was found to be safe and efficient in the induction and maintenance phases of therapy in CD and UC patients. Although patients receiving vedolizumab presented more frequent SAEs and infections compared with placebo, the promising data generated with this $\mathrm{Ab}$ led to a growing interest in developing other anti-integrin Abs, such as etrolizumab (rhuMAb 37 ), abrilumab (AMG 181), and PF-00547659, which are currently evaluated in clinical trials (Table 2, and references therein). PF-00547659 is a fully human $\mathrm{mAb}$ that binds to human mucosal addressin cell adhesion molecule (MAdCAM), which is 
predominantly expressed on the cell surface of high endothelial venules of organised intestinal lymphoid tissues (Peyer's patches, mesenteric lymph nodes). It was found to selectively reduce lymphocyte homing to the intestinal tract. Although compared to placebo, this $\mathrm{mAb}$ did not meet the primary endpoint of clinical response in moderate-to-severe $\mathrm{CD}$, it raised great hopes as it presented some appreciable pharmacological effects, which remain to be analysed further [98].

\section{Adverse effects of biologics}

Several clinical trials and meta-analyses have verified the efficacy and safety of biologicsbased therapies. The risk of SAEs associated with these therapies has been relatively lower compared to other conventional (immunosuppressive) treatments and some biologics have proved to be beneficial in the induction and maintenance of clinical remission and response [105,106]. However, cases of SAEs including hypersensitivity reactions, injection site reactions, skin cancers, drug-induced lupus, psoriasis, reactivation of latent tuberculosis, hepatotoxicity, lymphomas and solid tumour have been reported (Tables 1; Table 2). In addition, the high production cost of therapeutic mAbs remains a hurdle in maintaining the cost-effectiveness of these drugs [107,108].

Another serious issue that is encountered with certain biologics is the generation of anti-drug Abs (ADAs) that makes at least $40 \%$ of the patients receiving anti-TNF drugs secondary nonresponders. This loss of responsiveness mostly occurs in the case of patients receiving episodic therapy or in the presence of lower levels of ADAs against other anti-TNF agents received earlier (including biosimilars) [109]. According to previous studies, the formation of Abs against infliximab occurs in $61 \%$ of patients receiving episodic treatment and $44 \%$ of patients losing response to adalimumab were found to have developed $\mathrm{Ab}$ to adalimumab. It is a general observation and a source of concern that more and more cases of ADAs are reported in the literature [110-114] influencing the efficacy of treatment and the potential clinical improvement of patients under biotherapy. Sensitive assays have been developed to detect ADAs that are produced early in certain individuals and can dramatically affect the results of clinical trials and the efficacy of current treatments in patients $[110,115,116]$. A careful follow-up of patients all along their treatment should be performed. High serum concentrations of anti-TNF drugs are generally associated with improved clinical outcomes in UC patients. In contrast low concentrations have been shown to frequently associate with the formation of ADAs [117,118]. 
In terms of small molecules, apilimod mesylate (N-[(E)-(3-methylphenyl)methylideneamino] -6-morpholin-4-yl-2-(2-pyridin-2-ylethoxy)pyrimidin-4 amine; formerly STA-5326) that inhibits IL-12/IL-23, was evaluated in clinical trials including patients with CD [119]. Up to 700 subjects have been treated with mild-to-moderate side effects. However, apilimod did not meet the primary end points in phase-II inflammatory disease indications [120]. This molecule is currently evaluated in other indications.

ABX464 (8-chloro-N-[4-(trifluoromethoxy)phenyl]quinolin-2-amine) is a small molecule that induces IL-22 production in macrophages, which may have great interests in acting on intestine inflammation. Laquinimod (ABR-215062 or TV-5600; developed by Active Biotech and Teva) is another oral drug that that has inhibitory effects on antigen-presenting cells and $\mathrm{T}$ cells, resulting in reduced pro-inflammatory cytokine production. In randomised controlled trials laquinimod was efficacious for CD (Table 2). Head-to-head studies with existing treatments and longer term safety data are however needed at this stage of investigation.

The JAK (Janus kinase)-STAT pathway is a major signalling cascade downstream from the cytokine and growth factor receptors, and hence JAK inhibition has been shown to be potentially therapeutic in IBDs. Tofacitinib (Xeljanz) is a pan-JAK inhibitor currently available for treatment of UC [121]. Other molecules such as filgotinib and upadacitinib (JAK1 inhibitors) are under clinical trials for CD and UC.

Mongersen (GED-0301), an oral oligonucleotide drug containing an anti-SMAD7 (mothers against decapentaplegic homolog 7) oligonucleotide has proved to be able to restore signalling by mucosal anti-inflammatory cytokine TGF- $\beta 1$. Although positive results were obtained in phase II trials for CD with a clinical remission rate of $72 \%$ after two weeks of treatment, this drug was withdrawn from clinical studies in November 2017 due to disappointing results from an interim analysis of a phase-III study [89,102].

Small molecules targeting leukocyte trafficking are also currently investigated. One of them is the a4-integrin antagonist AJM300, an oral phenylalanine derivative, which is presently evaluated in phase-III clinical trials for UC (investigated in a small cohort of patients until now; Table 2). Amiselimod (MT1303; Biogen), ozanimod (RPC1063; Celgen) and etrasimod (APD334; Arena Pharmaceuticals) are other molecules that act as sphingosine-1-phosphate receptor (S1P) modulators, which lead to lymphocyte sequestration in lymph nodes and reduce the migration of lymphocytes to gastrointestinal tract. The development of 
amiselimod, which was in phase II-clinical trials for CD has been halted, as Biogen is currently focusing on other drugs from its portfolio. A phase-III clinical trial of ozanimod in patients with moderate-to-severe UC is ongoing. Etrasimod is also being tested in a phase-II trial in UC [96].

288

289

290

291

292

293

294

295

296

297

298

299

300

301

302

303

304

305

306

307

308

309

310

311

312

313

314

315

\section{Pros and Cons: how can we progress?}

Although the advent of all these therapeutic options greatly helps maintaining middle-term remission and improving the IBDs patients' quality of life to a certain extent, we must recognize that they remain mostly symptomatic and do not address the root genetic causes $[4-6,17,68]$. Besides, their high cost, severe impacts and SAEs of some of these treatments in the long-term, call for the development of cost-effective small molecule drugs that are disease-specific. In this context, several elements of the autophagy pathway might be key targets for novel therapeutic options.

\section{Autophagy, an Emerging Element in IBDs Regulation and a Novel Therapeutic Option}

\section{IBDs and autophagy}

Autophagy is a crucial intracellular pathway that continuously degrades, recycles and clears unnecessary or dysfunctional cellular components (e.g., damaged organelles, proteins abnormally folded or produced in excess). It is a finely gene-regulated and evolutionaryconserved process. Autophagy is prominent in the adaptation of cells to their environment and to maintain cell homeostasis, especially under stress conditions (nutrient deprivation, hypoxia, oxidative stress, changes of intracellular level of calcium). It is thus a central actor in cellular processes, such as development, lineages differentiation, and immunity.

Among the pathways that have been associated with so far identified IBDs risk loci, autophagy seems to be a significant one. Since the identification of the autophagy-related gene (ATG) 16L1 (Box 3) as a major hit in IBDs genetics in 2006 [122], various studies have repeatably established a link between IBDs, ATG16L1 and the process of autophagy [123130]. It has been shown that ATG16L1 modulates ubiquitination of the adaptor protein sequestosome 1 (SQSTM1)/p62 through the neddylation of cullin-3 (a core element of a complex known as an E3 ubiquitin ligase), leading thus to the suppression of IL-1B signaling [131]. Animal models with mutations in Atg16l1 (e.g., Atg16L1/T300A knockin mice and especially Atg16L1/Xbp $\Delta \mathrm{IEC}$ mice) have been engineered and used to reinforce our understanding of the importance of this Atg in the development of IBDs [132,133]. Other ATGs such as genes encoding immune-related GTPase M (IRGM) [134-137], leucine-rich 
Some alterations -either upregulation or downregulation- in several autophagy pathways, including macroautophagy, chaperone-mediated autophagy (CMA; Box 1), mitophagy and other forms of autophagy, have been implicated in numerous (auto)immune and inflammatory disorders, such as SLE, Sjögren's syndrome ( $\mathrm{SjS})$, RA, psoriasis, some neuroinflammatory and neurodegenerative diseases including MS, chronic inflammatory demyelinating polyneuropathies, amyotrophic lateral sclerosis (ALS), and Huntington's, Alzheimer's, and Parkinson's diseases [126,141,143-151]. Hence components of this central metabolic system recently emerged as a particularly attracting, and even key therapeutic target in many of them [152-159]. A previous study has shown, for example, that an MTOR inhibitor molecule (Figure 2), namely an haloacyl aminopyridine-based molecule called P2281, was efficient in a murine model of DSS-colitis by inhibiting T cell function [160]. Another report, in patients, also concluded that rapamycin/sirolimus, a macrocyclic triene antibiotic, which binds to the cytosolic 12-kDa tacrolimus-binding protein (FKBP12) and also inhibits MTOR pathway, could represent a good candidate to treat CD patients [161]. In this retrospective analysis of patients treated with rapamycin, 5 of the $11 \mathrm{UC}$ patients and all of the $3 \mathrm{CD}$ patients achieved clinical remission. An additional $2 \mathrm{UC}$ patients achieved clinical response. The remaining $4 \mathrm{UC}$ patients did not respond to rapamycin treatment. Mucosal healing was achieved in 5 of $11 \mathrm{UC}$ patients and 2 of $3 \mathrm{CD}$ patients. Clinical response to treatment occurred at least 2 weeks after treatment was started. The only significant side effect reported was minor gastrointestinal distress [161]. This report confirms some data generated in TNBS-treated mice, the intestinal inflammation and colitis was ameliorated by rapamycin and also by trehalose [162]. P2281, rapamycin and trehalose all affect the macroautophagy pathway (Figure 2). Besides their pathophysiological interest, the aforementioned results present potential pharmacological evidence supporting that targeting autophagy using small molecules can be robust for future treatment.

\section{The autophagy pathways: novel options to treat patients with IBDs}

As described above, autophagy plays multiple roles in IBDs pathogenesis. Under the control of genes such as ATG16L1, IRGM, LRRK2, and NOD2/CARD15, the expression of which appears deregulated in susceptible patients, several vital functions assumed by autophagy processes are severely altered. As a matter of consequences, intracellular bacterial killing, antimicrobial peptide secretion by Paneth cells, goblet cell functions, proinflammatory 
cytokine production by macrophages, antigen presentation and processing by antigenpresenting cells (DCs, B cells, macrophages), and endoplasmic reticulum stress response in enterocytes are deregulated (Figure 3) $[4,5,17,142,144]$. The first line of defence for pathogenic infection and many other aspects of the innate and adaptative immune response are profoundly unbalanced. Therefore, elements of autophagic pathways represent targets of choice to probe in novel therapeutic options of IBDs patient's treatment.

\section{The mutliplicity of targets of current anti-autophagy regulators}

Developing an effective treatment targeting specific components of autophagic pathways requires to identify what are the elements of the said pathways that are crucial, whose expression is specifically modified (activated or repressed) as a result of the pathophysiological context, and for which we possess tools (existing drugs or newly developed molecules) that reach their target (preferably one) without generating side effects in unrelated metabolic circuits. In general, small molecules possess several pharmacological receptors, and targeting some of them may generate unwanted reactions that hamper or limit their use due to their deleterious influence on vital functions.

A number of activators and inhibitors of autophagy have been described (Figure 2) [153$155,157,158,163-168]$, and a growing list of patents have been filed. They notably include phytochemicals and anti-oxidants (e.g., polyphenol, curcumin, resveratrol) [169]. In almost all cases, their fine specificity is not known. Few of them, if any, interact with one single target of a specific autophagic process (e.g., macroautophagy, microautophagy, CMA, mitophagy, lipophagy and others), and the fact that pharmacologic molecules develop several effects, via distinct cell receptors and intracellular pathways, can render them harmful to health. An illustrative example is hydroxychloroquine (HCQ; Plaquenil, Axemal, Dolquine, Quensyl). HCQ a potent autophagy inhibitor, which affects the lysosomal pH (Figure 2) but also, for example inhibits CXCL12/CXCR4 signaling resulting in reduced phosphorylation of extracellular signal-regulated kinases (ERK) and signal transducer and activator of transcription 3 (STAT3). The main concern regarding HCQ is its toxicity with regard to retina that imposes a regular ophthalmic follow-up to evaluate the extent of eventual retinopathy in susceptible individuals [156,170]. Identifying the retinal target of HCQ should help in generating a class of molecules, which keep their primary efficacy without developing their secondary deleterious effects. 
Rapamycin that was discussed above, is another example of a molecule that exerts potent effects on different targets. It has been shown to acutely inhibit MTORC1 whereas chronic exposure to rapamycin can also inhibit MTORC2, two functionally distinct complexes in mammalian cells [171]. These complexes share some protein components, but their distinctive activities are defined by their unique components, namely Raptor (MTORC1), and Rictor and mSin1 (MTORC2). Rapamycin forms a tripartite complex with MTOR and FKBP12 (see above) that leads to MTORC1 inhibition. The complexity of its effects on MTORC2 is not completely resolved [172].

Another example of this complexity emerges with metformin (Glucophage, among other names; Box 4), a synthetic derivative of guanidine which acts as an inducer of autophagy but also displays several other effects via different targets. Several independent studies have shown that metformin ameliorates IBDs [173-175]. In an experimental model, administration of metformin reduced inflammation through the inhibition of p-STAT3, IL-17 and p-MTOR expression and the increased expression of p-AMPK and Foxp3 [173]. It was also demonstrated that metformin limits DSS-induced intestinal barrier disruption by a mechanism involving the inhibition of c-Jun N-terminal kinase activation via an AMPKa1-dependent signaling pathway [174].

\section{Selective regulators of autophagy}

These recent years, a great deal of effort was done to identify more selective drug's targets, in particular, based on interactome or metabolomics studies, and accordingly to redesign some molecules that were discarded to render them more selective of the chosen target. This kind of investigation is especially important in IBDs to adapt treatment in a frame of personalized and precision medicine that aims at optimizing treatment practices and at significantly reduce SAEs.

Example of this new family of molecules is the peptide LR12 [176] of sequence HLQEEDTGEYGCV-NH2 that inhibits the triggering receptor expressed on myeloid cells 1 (TREM-1). LR12 was shown to correct the severity of colitis clinically, endoscopically and histologically in a DSS-induced mouse model of colitis [177]. TREM-1 is expressed on the majority of innate immune cells and to a lesser extent on parenchymal cells. The frequency of TREM-1-expressing neutrophils and recruited macrophages has been found to be higher in inflamed than in non-inflamed biopsies from patients with UC and CD [178]. Injection of LR12 peptide in DSS-induced model mice generated a significant increase of 

(HSPA8 and HSP90AA1) protein expression. This impressive effect of LR12 peptide was confirmed genetically using Trem-1 knockout mice [177]. TREM-1 inhibition prevented dysbiosis.

To our knowledge, the cell-permeable trans-activator of transcription (TAT)-coiled-coil, moesin-like BCL2-interacting protein (BECLIN)-1 peptide construct (YGRKKRRQRRRGGTNVFNATFEIWHDGEFGT) [179], which has shown some promise in several neurological, infectious and tumoral settings and is now commercialized, has not been evaluated in experimental models of IBDs. TAT-BECLIN peptide might have interesting applications since it has been proposed that BECLIN-1 regulates TJ barrier via endocytosis of occludin (a $65-\mathrm{kDa}$ tetraspan integral membrane protein) in an ERK- and a MTORC2-dependent way [180].

P140 (Rigerimod, IPP-201101) is another peptide that selectively targets autophagy processes, and more especially CMA. This 21-mer phosphopeptide corresponding to the sequence H-RIHMVYSKRSGKPRGYAFIEY-OH (residues 131-151) was described in 2003 [181]. It was initially spotted in a cellular screening assay using overlapping peptides covering the whole spliceosomal $\mathrm{U} 1-70 \mathrm{~K}$ protein and $\mathrm{CD}^{+} \mathrm{T}$ cells collected from MRL/lpr mice lymph nodes. A number of analogues have been produced and the one that possesses the most favorable properties identified nowadays contains a phosphoserine residue in position 140, which is crucial for its activity and stability [182-185]. P140 is not immunogenic [185], it is safe and displays no immunosuppressive activity in mouse and human settings [186190]. It was shown to directly interact with HSPA8 [182,191] and to inhibit the chaperone activity of the latter $[182,183]$. It also alters HSPA8 shuttling between the cytoplasm and the nucleus/nucleoli in case of stress [192]. It has been shown in vitro and in vivo that P140 enters MRL/lpr spleen B cells via a clathrin-dependent pathway and accumulates into lysosomes [148]. Notable effects associated with different components of the autophagy process were identified after treating cells and autoimmune mice with P140. The levels of HSPA8 and LAMP2A, which are overexpressed in MRL/lpr B cells, are corrected after P140 treatment. P140 has no direct effect on B cell receptor signaling in memory, naive, mature, transitional, or B1 human cells, suggesting that it does not alter B cell survival and maturation in these B cell subsets [190]. However, likely as a matter of consequence resulting from its interaction with HSPA8, it strongly reduces the overexpression of major histocompatibility complex (MHC) class II molecules on lupus B cells acting as antigen- 
presenting cells and hampers peptide-MHC molecule loading in late lysosomal vesicles $[143,148,183,190]$. This impressive effect shown both in mice and in human settings decelerates the complex signaling cascade leading to the final production of pathogenic autoAbs. P140 effectively down-regulates T cell activation [187] and consequently reduces the differentiation of human B cells into plasma cells and IgG secretion [190]. Altogether, these results indicate that by interfering with overactivated autophagy processes, P140 peptide efficiently affects the processing of endogenous (auto)antigen, the peptide loading to MHCII molecules, and the entire down-stream deleterious proinflammatory events. It must be emphasized that the normal immune system is not affected in this scheme, and that experimental MRL/lpr mice are still capable of developing cellular and humoral immune reactions towards a pathogen [187]. In a multicenter, randomized, placebo-controlled phaseIIb study for lupus, P140/Lupuzor was found to be safe and met its primary efficacy endpoints, confirming pre-clinical data generated in MRL/lpr lupus-prone mice [189]. Lupuzor is currently evaluated in phase-III clinical trials in the US, Europe, and Mauritius. An open-labeled trial including several hundred lupus patients worldwide is planned. It is also evaluated in the context of other autoimmune or inflammatory conditions and showed some promises in preclinical studies including experimental animal models [143,150,151]. Preliminary data tend to show that P140 could also be a highly valuable tool for treating IBDs. Future investigations based on chemically- and genetically-induced murine models, organoids, and cells collected from patients with CD and UC are warranted to determine if P140 could be exploited as a potent drug in affected patients.

\section{Concluding remarks}

Research for therapeutic options to treat IBDs identified new compounds targeting elements involved in maintaining intestinal homeostasis and identified biomarkers allowing detection of inter- and intra-personal variations in patients (see Clinician's Corner). In the pipeline of new possible treatments, elements of the autophagy process are particularly indicated. In this context, a crucial aspect that has largely hampered the clinical applications of autophagybased therapeutic strategies is that until now, among the large set of existing activators/inhibitors molecules, very few are strictly selective to one autophagy pathway and one target. In general, molecules such as rapamycin, HCQ, trehalose, metformin, perifosine (inhibitor of protein kinase B or AKT), minocycline (a semi-synthetic tetracycline derivative with dual properties on autophagy processes), or niclosamide (inhibitor of MTORC1) interact with several targets and receptors [193]. This favors SAEs and therefore limits their use as 
drugs. Intense research is therefore devoted to identification of small molecules and peptides to precisely up- or down-regulate specific autophagy processes that are pathologically defective without interfering with the other autophagy processes.

Another aspect that further complicates the design of new strategies based on deregulated autophagy is that in a single individual, autophagic activity can be raised in certain organs or tissues, and diminished in others [143,194], in an order that can vary from patient to patient [194]. More research is therefore eagerly needed to understand the interplay between the different autophagic pathways that are supposed to protect cells and ensured cell homeostasis, and the effects of counterbalance between them in the same organ, and in cells of different organs (see Outstanding Questions). We should not have a reductionist definition of phenomena, and just claim that autophagy, as a whole, is exacerbated or compromised in a particular illness. Instead, we would be well advised to more precisely define the type of autophagy pathway, and in which organ and cell subtype these defaults occur [168]. Further investigation is also needed to discover valid predicting markers of drug responsiveness. This whole set of information is crucial to direct rescuing molecules to specific sites of autophagy dysregulation, and to design more personalized and safe therapeutic options. Finally, new directions taking into account the specific infectious facet of IBDs-affected patients should lead to new precision medicine development based on molecules that selectively target xenophagy, which would contribute to eliminating invading pathogens and therefore an innovative segment that deserves most attention.

\section{Acknowledgments}

We thank Hang Nguyen and Hélène Jeltsch-David for critically reading the manuscript. SM thanks the French Centre National de la Recherche Scientifique, the Laboratory of Excellence Medalis (ANR-10-LABX-0034), Initiative of Excellence (IdEx), Strasbourg University, and the University of Strasbourg Institute for Advanced Study (USIAS). SM also acknowledges the support of the TRANSAUTOPHAGY COST Action CA15138 and the French club of Autophagy (CFATG).

\section{Conflict of interest}

SM has the following conflicts of interest to disclose: Research funding (paid to institution) and past consultant for ImmuPharma; co-inventor of CNRS-ImmuPharma patents on P140 
509 peptide. The authors declare that the research was conducted in the absence of any 510 commercial or financial relationships that could construed as a potential conflict of interest. 
512 1. Cho JH. (2008) The genetics and immunopathogenesis of inflammatory bowel disease. Nat.

513 Rev. Immunol. 8, 458-466

$514 \quad$ 2. Baumgart DC, Sandborn WJ. (2012) Crohn's disease. Lancet 380, 1590-1605

515 3. Lerner A, Matthias T. (2015) Changes in intestinal tight junction permeability associated with industrial food additives explain the rising incidence of autoimmune disease. Autoimmun.

518 4. Yadav V, Varum F, Bravo R, Furrer E, Bojic D, Basit AW. (2016) Inflammatory bowel 519 disease: exploring gut pathophysiology for novel therapeutic targets. Transl. Res. 176, 38-68

520 5. Zundler S, Neurath MF. (2015) Immunopathogenesis of inflammatory bowel diseases: 521 functional role of T cells and T cell homing. Clin. Exp. Rheumatol. 33, S19-S28

522 6. de Souza HSP, Fiocchi C. (2016) Immunopathogenesis of IBD: current state of the art. Nat. Rev. Gastroenterol. Hepatol. 13, 13-27

7. Park JH, Peyrin-Biroulet L, Eisenhut M, Shin J Il. (2017) IBD immunopathogenesis: a comprehensive review of inflammatory molecules. Autoimmun. Rev. 16, 416-426

8. Khor B, Gardet A, Xavier RJ. (2011) Genetics and pathogenesis of inflammatory bowel disease. Nature 474, 307-317

528 9. Citi S. (2018) Intestinal barriers protect against disease. Science 359, 1097-1098

529 10. Luettig J, Rosenthal R, Barmeyer C, Schulzke JD. (2015) Claudin-2 as a mediator of leaky gut barrier during intestinal inflammation. Tissue barriers 3, e977176

11. Norén E, Almer S, Söderman J. (2017) Genetic variation and expression levels of tight junction genes identifies association between MAGI3 and inflammatory bowel disease. BMC Gastroenterol. 17, 68

12. Wei SC, Levine JH, Cogdill AP, et al. (2017) Distinct cellular mechanisms underlie antiCTLA-4 and anti-PD-1 checkpoint blockade. Cell 170, 1120-1133

13. Yan J, Hedl M, Abraham C. (2017) An inflammatory bowel disease-risk variant in INAVA

14. Mohanan V, Nakata T, Desch AN, et al. (2018) C1orf106 is a colitis risk gene that regulates stability of epithelial adherens junctions. Science 359, 1161-1166

540 15. Nighot P, Ma T. (2016) Role of autophagy in the regulation of epithelial cell junctions. Tissue 
16. Boyapati R, Satsangi J, Ho G-T. (2015) Pathogenesis of Crohn's disease. F1000Prime Rep. 7 , 44

17. Ke P, Shao B-Z, Xu Z-Q, Chen X-W, Liu C. (2017) Intestinal autophagy and its pharmacological control in inflammatory bowel disease. Front. Immunol. 7, 695

18. Momozawa Y, Dmitrieva J, Théâtre E, et al. (2018) IBD risk loci are enriched in multigenic regulatory modules encompassing putative causative genes. Nat. Commun. 9, 2427

19. Sands BE. (2015) Biomarkers of inflammation in inflammatory bowel disease. Gastroenterology 149, 1275-1285

20. Mitsuyama K, Niwa M, Takedatsu H, et al. (2016) Antibody markers in the diagnosis of inflammatory bowel disease. World J. Gastroenterol. 22, 1304-1310

21. Smids C, Horjus Talabur Horje CS, Groenen MJM, van Koolwijk EHM, Wahab PJ, van Lochem EG. (2017) The value of serum antibodies in differentiating inflammatory bowel

22. Baumgart DC, Grittner U, Steingräber A, Azzaro M, Philipp S. (2011) Frequency, phenotype, outcome, and therapeutic impact of skin reactions following initiation of adalimumab therapy: experience from a consecutive cohort of inflammatory bowel disease patients. Inflamm. Bowel Dis. 17, 2512-2520

23. Eken A, Singh AK, Oukka M. (2014) Interleukin 23 in Crohn's disease. Inflamm. Bowel Dis. 20, 587-595

24. Rowland SL, Riggs JM, Gilfillan S, et al. (2014) Early, transient depletion of plasmacytoid dendritic cells ameliorates autoimmunity in a lupus model. J. Exp. Med. 211, 1977-1991

25. Ah Kioon M-D, Lindsay R, Chen J, et al. (2018) FRI0398 Sl-401, a novel targeted therapy directed to the interleukin-3 receptor (CD123), kills plasmacytoid dendritic cells from systemic sclerosis patients. Ann. Rheum. Dis. 77, 731-732

26. Chamouard P, Monneaux F, Richert Z, et al. (2009) Diminution of circulating CD4+ CD25 high T cells in naive Crohn's disease. Dig. Dis. Sci. 54, 2084

27. van Herk EH, te Velde AA. (2016) Treg subsets in inflammatory bowel disease and colorectal carcinoma: Characteristics, role, and therapeutic targets. J. Gastroenterol. Hepatol. 31, 13931404 
28. Carabotti M, Scirocco A, Maselli MA, Severi C. (2015) The gut-brain axis: interactions between enteric microbiota, central and enteric nervous systems. Ann. Gastroenterol. 28, 203209

29. Bel S, Pendse M, Wang Y, et al. (2017) Paneth cells secrete lysozyme via secretory autophagy during bacterial infection of the intestine. Science 357, 1047-1052

30. Jameson KG, Hsiao EY. (2018) Linking the gut microbiota to a brain neurotransmitter. Trends Neurosci. 41, 413-414

31. Yang L, Liu C, Zhao W, et al. (2018) Impaired Autophagy in Intestinal Epithelial Cells Alters Gut Microbiota and Host Immune Responses. McBain AJ, ed. Appl. Environ. Microbiol. 84, e00880-18

32. Lane ER, Zisman TL, Suskind DL. (2017) The microbiota in inflammatory bowel disease: current and therapeutic insights. J. Inflamm. Res. 10, 63-73

33. Litvak Y, Byndloss MX, Bäumler AJ. (2018) Colonocyte metabolism shapes the gut microbiota. Science 362 , eaat 9076

34. Tamboli CP, Neut C, Desreumaux P, Colombel JF. (2004) Dysbiosis in inflammatory bowel disease. Gut 53, 1-4

35. Qin J, Li R, Raes J, et al. (2010) A human gut microbial gene catalogue established by metagenomic sequencing. Nature 464, 59-65

36. Mizoguchi A. (2012) Animal models of inflammatory bowel disease. In: Progress in Molecular Biology and Translational Science. Vol 105. Academic Press; 2012:263-320.

37. Kirsner JB, Elchlepp J. (1957) The production of an experimental ulcerative colitis in rabbits. Trans. Assoc. Am. Physicians 70, 102-119

38. Jiminez JA, Uwiera TC, Douglas Inglis G, Uwiera RRE. (2015) Animal models to study acute and chronic intestinal inflammation in mammals. Gut Pathog. 7, 29

39. Castellanos JG, Woo V, Viladomiu M, et al. (2018) Microbiota-Induced TNF-like Ligand 1A Drives Group 3 Innate Lymphoid Cell-Mediated Barrier Protection and Intestinal T Cell Activation during Colitis. Immunity 49, 1077-1089

40. Carvalho FA, Barnich N, Sivignon A, et al. (2009) Crohn's disease adherent-invasive Escherichia coli colonize and induce strong gut inflammation in transgenic mice expressing human CEACAM. J. Exp. Med. 206, 2179-2189

41. Bretin A, Lucas C, Larabi A, et al. (2018) AIEC infection triggers modification of gut 
microbiota composition in genetically predisposed mice, contributing to intestinal inflammation. Sci. Rep. 8, 12301

42. te Velde AA, Verstege MI, Hommes DW. (2006) Critical appraisal of the current practice in murine TNBS-induced colitis. Inflamm. Bowel Dis. 12, 995-999

43. Perše M, Cerar A. (2012) Dextran sodium sulphate colitis mouse model: traps and tricks. Biomed Res. Int. 2012, 718617

44. Melhem H, Hansmannel F, Bressenot A, et al. (2015) Methyl-deficient diet promotes colitis and SIRT1-mediated endoplasmic reticulum stress. Gut 65, 595-606

45. Eri R, McGuckin MA, Wadley R. (2012) T cell transfer model of colitis: a great tool to assess the contribution of T cells in chronic intestinal inflammation. Methods Mol. Biol. 844, 261275

46. Lichtiger S, Present DH, Kornbluth A, et al. (1994) Cyclosporine in Severe Ulcerative Colitis Refractory to Steroid Therapy. N. Engl. J. Med. 330, 1841-1845

47. Campieri M, Ferguson A, Doe W, Persson T, Nilsson LG, Group GBS. (1997) Oral budesonide is as effective as oral prednisolone in active Crohn's disease. Gut 41, 209-214

48. Steinhart AH, Ewe K, Griffiths AM, Modigliani R, Thomsen OO. (2003) Corticosteroids for maintenance of remission in Crohn's disease. Cochrane Database Syst. Rev. CD000301

49. Sandborn WJ, Faubion WA. (2004) Biologics in inflammatory bowel disease: how much progress have we made? Gut 53, 1366-1373

50. Schreiber S, Rutgeerts P, Fedorak RN, et al. (2005) A randomized, placebo-controlled trial of certolizumab pegol (CDP870) for treatment of Crohn's disease. Gastroenterology 129, 807818

51. Sandborn WJ, Feagan BG, Stoinov S, et al. (2007) Certolizumab pegol for the treatment of Crohn's disease. N. Engl. J. Med. 357, 228-238

52. Targan SR, Feagan BG, Fedorak RN, et al. (2007) Natalizumab for the treatment of active Crohn's disease: results of the ENCORE Trial. Gastroenterology 132, 1672-1683

53. Sandborn WJ, Feagan BG, Fedorak RN, et al. (2008) A randomized trial of ustekinumab, a human interleukin-12/23 monoclonal antibody, in patients with moderate-to-severe Crohn's disease. Gastroenterology 135, 1130-1141

54. Schoepfer AM, Vavricka SR, Binek J, et al. (2009) Efficacy and safety of certolizumab pegol induction therapy in an unselected Crohn's disease population: results of the FACTS survey. 
55. Soler D, Chapman T, Yang L-L, Wyant T, Egan R, Fedyk ER. (2009) The binding specificity and selective antagonism of vedolizumab, an anti- $\alpha 4 \beta 7$ integrin therapeutic antibody in development for inflammatory bowel diseases. J. Pharmacol. Exp. Ther. 330, 864-875

56. Ogata H, Kato J, Hirai F, et al. (2011) Double-blind, placebo-controlled trial of oral tacrolimus (FK506) in the management of hospitalized patients with steroid-refractory ulcerative colitis. Inflamm. Bowel Dis. 18, 803-808

57. Ham M, Moss AC. (2012) Mesalamine in the treatment and maintenance of remission of ulcerative colitis. Expert Rev. Clin. Pharmacol. 5, 113-123

58. Sandborn WJ, Gasink C, Gao L-L, et al. (2012) Ustekinumab induction and maintenance therapy in refractory Crohn's disease. N. Engl. J. Med. 367, 1519-1528

59. Curkovic I, Egbring M, Kullak-Ublick GA. (2013) Risks of inflammatory bowel disease treatment with glucocorticosteroids and aminosalicylates. Dig. Dis. 31, 368-373

60. Feagan BG, Rutgeerts P, Sands BE, et al. (2013) Vedolizumab as induction and maintenance therapy for ulcerative colitis. N. Engl. J. Med. 369, 699-710

61. Frei P, Biedermann L, Nielsen OH, Rogler G. (2013) Use of thiopurines in inflammatory bowel disease. World J. Gastroenterol. 19, 1040-1048

62. Panaccione R, Colombel J-F, Sandborn WJ, et al. (2013) Adalimumab maintains remission of Crohn's disease after up to 4 years of treatment: data from CHARM and ADHERE. Aliment. Pharmacol. Ther. 38, 1236-1247

63. Zenlea T, Peppercorn MA. (2014) Immunosuppressive therapies for inflammatory bowel disease. World J. Gastroenterol. 20, 3146-3152

64. Herfarth HH, Kappelman MD, Long MD, Isaacs KL. (2015) Use of methotrexate in the treatment of inflammatory bowel diseases. Inflamm. Bowel Dis. 22, 224-233

65. Yu L, Yang X, Xia L, et al. (2015) Infliximab preferentially induces clinical remission and mucosal healing in short course Crohn's disease with luminal lesions through balancing abnormal immune response in gut mucosa. Mediators Inflamm. 2015, 1-9

66. Feagan BG, Sandborn WJ, Gasink C, et al. (2016) Ustekinumab as induction and maintenance therapy for Crohn's disease. N. Engl. J. Med. 375, 1946-1960

67. Colombel J-F, Sands BE, Rutgeerts P, et al. (2017) The safety of vedolizumab for ulcerative colitis and Crohn's disease. Gut 66, 839-851 
68. Coskun M, Vermeire S, Nielsen OH. (2017) Novel targeted therapies for inflammatory bowel disease. Trends Pharmacol. Sci. 38, 127-142

69. Flamant M, Paul S, Roblin X. (2017) Golimumab for the treatment of ulcerative colitis. Expert Opin. Biol. Ther. 17, 879-886

70. Gionchetti P, Rizzello F, Annese V, et al. (2017) Use of corticosteroids and immunosuppressive drugs in inflammatory bowel disease: clinical practice guidelines of the Italian group for the study of inflammatory bowel disease. Dig. Liver Dis. 49, 604-617

71. Allocca M, Furfaro F, Gilardi D, D'Alessio S, Danese S. (2018) Can IL-23 be a good target for ulcerative colitis? Best Pract. Res. Clin. Gastroenterol. 32-33, 95-102

72. Dragoni G, Le Grazie M, Orlandini B, Rogai F. (2019) Golimumab in inflammatory bowel diseases: present and future scenarios. Clin. J. Gastroenterol. 12, 1-9

73. Yokoyama T, Ohta A, Motoya S, et al. (2018) Efficacy and safety of oral budesonide in patients with active Crohn's disease in Japan: a multicenter, double-blind, randomized, parallel-group phase 3 study. Inflamm. Intest. Dis. 2, 154-162

74. Herfarth H, Barnes EL, Valentine JF, et al. (2018) Methotrexate Is Not Superior to Placebo in Maintaining Steroid-Free Response or Remission in Ulcerative Colitis. Gastroenterology 155, 1098-1108

75. Zhou B, Xia X, Wang P, et al. (2018) Induction and amelioration of methotrexate-induced gastrointestinal toxicity are related to immune response and gut microbiota. EBioMedicine 33, $122-133$

76. Kwak MS, Kim K-J, Cheon JH, et al. (2018) Comparison of Concomitant Mesalamine and Immunomodulator Therapy and Immunomodulator Monotherapy for Crohn's Disease. Gastroenterol. Res. Pract. 2018, 4826973

77. Bandzar S, Gupta S, Platt MO. (2013) Crohn's disease: A review of treatment options and current research. Cell. Immunol. 286, 45-52

78. Cholapranee A, Hazlewood GS, Kaplan GG, Peyrin-Biroulet L, Ananthakrishnan AN. (2017) Systematic review with meta-analysis: comparative efficacy of biologics for induction and maintenance of mucosal healing in Crohn's disease and ulcerative colitis controlled trials. Aliment. Pharmacol. Ther. 45, 1291-1302

79. Greener T, Boland K, Steinhart AH, Silverberg MS. (2017) The Unfinished Symphony: Golimumab Therapy for Anti-Tumour Necrosis Factor Refractory Crohn's Disease. J. Crohn's Colitis 12, 458-464 
80. Aubin F, Carbonnel F, Wendling D. (2013) The complexity of adverse side-effects to biological agents. J. Crohn's Colitis 7, 257-262

81. Ding NS, Hart A, De Cruz P. (2016) Systematic review: predicting and optimising response to anti-TNF therapy in Crohn's disease - algorithm for practical management. Aliment. Pharmacol. Ther. 43, 30-51

82. Quezada SM, McLean LP, Cross RK. (2018) Adverse events in IBD therapy: the 2018 update. Expert Rev. Gastroenterol. Hepatol. 12, 1183-1191

83. Shivaji UN, Sharratt CL, Thomas T, et al. (2019) Review article: managing the adverse events caused by anti-TNF therapy in inflammatory bowel disease. Aliment. Pharmacol. Ther. https://doi.org/10.1111/apt.15097

84. Katsanos KH, Papamichael K, Feuerstein JD, Christodoulou DK, Cheifetz AS. (2018) Biological therapies in inflammatory bowel disease: Beyond anti-TNF therapies. Clin. Immunol. doi:10.1016/j.clim.2018.03.004

85. Niederreiter L, Erik Adolph T, Kaser A. (2013) Anti-IL-12/23 in Crohn's disease: bench and bedside. Curr. Drug Targets 14, 1379-1384

86. D'haens G, Sandborn WJ, Colombel JF, et al. (2014) A phase II study of laquinimod in Crohn's disease. Gut 64, 1227-1235

87. Pan W, Köck K, Rees WA, et al. (2014) Clinical pharmacology of AMG 181, a gut-specific human anti- $\alpha 4 \beta 7$ monoclonal antibody, for treating inflammatory bowel diseases. Br. J. Clin. Pharmacol. 78, 1315-1333

88. Vermeire S, O’Byrne S, Keir M, et al. (2014) Etrolizumab as induction therapy for ulcerative colitis: a randomised, controlled, phase 2 trial. Lancet 384, 309-318

89. Monteleone G, Neurath MF, Ardizzone S, et al. (2015) Mongersen, an oral SMAD7 antisense oligonucleotide, and Crohn's disease. N. Engl. J. Med. 372, 1104-1113

90. Panaccione R, Sandborn WJ, Gordon GL, et al. (2015) Briakinumab for treatment of Crohn's disease: results of a randomized trial. Inflamm. Bowel Dis. 21, 1329-1340

91. Yoshimura N, Watanabe M, Motoya S, et al. (2015) Safety and efficacy of AJM300, an oral antagonist of $\alpha 4$ integrin, in induction therapy for patients with active ulcerative colitis. Gastroenterology 149, 1775-1783

92. Fiorino G, Gilardi D, Danese S. (2016) The clinical potential of etrolizumab in ulcerative colitis: hypes and hopes. Therap. Adv. Gastroenterol. 9, 503-512 
93. Chebli K, Papon L, Paul C, et al. (2017) The anti-HIV candidate ABX464 dampens intestinal inflammation by triggering IL-22 production in activated macrophages. Sci. Rep. 7, 4860

94. Feagan BG, Sandborn WJ, D'Haens G, et al. (2017) Induction therapy with the selective interleukin-23 inhibitor risankizumab in patients with moderate-to-severe Crohn's disease: a randomised, double-blind, placebo-controlled phase 2 study. Lancet 389, 1699-1709

95. Martineau C, Flourié B, Wils P, et al. (2017) Efficacy and safety of golimumab in Crohn's disease: a French national retrospective study. Aliment. Pharmacol. Ther. 46, 1077-1084

96. Peyrin-Biroulet L, Christopher R, Behan D, Lassen C. (2017) Modulation of sphingosine-1phosphate in inflammatory bowel disease. Autoimmun. Rev. 16, 495-503

97. Sandborn WJ, Feagan BG, Panes J, et al. (2017) Safety and efficacy of ABT-494 (upadacitinib), an oral jak1 inhibitor, as induction therapy in patients with Crohn's disease: results from celest. Gastroenterology 152, S1308-S1309

98. Sandborn WJ, Lee SD, Tarabar D, et al. (2017) Phase II evaluation of anti-MAdCAM antibody PF-00547659 in the treatment of Crohn's disease: report of the OPERA study. Gut 67, 18241835

99. Sands BE, Chen J, Feagan BG, et al. (2017) Efficacy and safety of MEDI2070, an antibody against interleukin 23, in patients with moderate to severe Crohn's disease: a phase 2a study. Gastroenterology 153, 77-86

100. Vermeire S, Schreiber S, Petryka R, et al. (2017) Clinical remission in patients with moderateto-severe Crohn's disease treated with filgotinib (the FITZROY study): results from a phase 2, double-blind, randomised, placebo-controlled trial. Lancet 389, 266-275

101. Vermeire S, Sandborn WJ, Danese S, et al. (2017) Anti-MAdCAM antibody (PF-00547659) for ulcerative colitis (TURANDOT): a phase 2, randomised, double-blind, placebo-controlled trial. Lancet 390, 135-144

102. Feagan BG, Sands BE, Rossiter G, et al. (2018) Effects of Mongersen (GED-0301) on endoscopic and clinical outcomes in patients with active Crohn's disease. Gastroenterology $154,61-64$

103. Sandborn WJ, Ferrante M, Bhandari BR, et al. (2018) 882 - Efficacy and safety of antiinterleukin-23 therapy with Mirikizumab (LY3074828) in patients with moderate-to-severe ulcerative colitis in a phase 2 study. Gastroenterology 154, S-1360-S-1361

104. Lima XT, Abuabara K, Kimball AB, Lima HC. (2009) Briakinumab. Expert Opin. Biol. Ther. 9, 1107-1113 
105. D'haens G. (2007) Risks and benefits of biologic therapy for inflammatory bowel diseases. Gut $56,725-732$

106. Beaugerie L, Carrat F, Colombel J-F, et al. (2014) Risk of new or recurrent cancer under immunosuppressive therapy in patients with IBD and previous cancer. Gut, 63, 1416-1423

107. Marchetti M, Liberato NL. (2014) Biological therapies in Crohn's disease: are they costeffective? A critical appraisal of model-based analyses. Expert Rev. Pharmacoecon. Outcomes Res. $14,815-824$

108. Pillai N, Dusheiko M, Burnand B, Pittet V. (2017) A systematic review of cost-effectiveness studies comparing conventional, biological and surgical interventions for inflammatory bowel disease. PLoS One 12, e0185500

109. Ha C, Mathur J, Kornbluth A. (2015) Anti-TNF levels and anti-drug antibodies, immunosuppressants and clinical outcomes in inflammatory bowel disease. Expert Rev. Gastroenterol. Hepatol. 9, 497-505

110. Yanai H, Lichtenstein L, Assa A, et al. (2015) Levels of drug and antidrug antibodies are associated with outcome of interventions after loss of response to infliximab or adalimumab. Clin. Gastroenterol. Hepatol. 13, 522-530

111. Krishna M, Nadler SG. (2016) Immunogenicity to biotherapeutics - the role of anti-drug immune complexes. Front. Immunol. 7, 21

112. Jani M, Isaacs JD, Morgan AW, et al. (2017) High frequency of antidrug antibodies and association of random drug levels with efficacy in certolizumab pegol-treated patients with rheumatoid arthritis: results from the BRAGGSS cohort. Ann. Rheum. Dis. 76, 208-213

113. Kay J, Isaacs JD. (2017) Clinical trials of biosimilars should become more similar. Ann. Rheum. Dis. 76, 4-6

114. Moots RJ, Xavier RM, Mok CC, et al. (2017) The impact of anti-drug antibodies on drug concentrations and clinical outcomes in rheumatoid arthritis patients treated with adalimumab, etanercept, or infliximab: Results from a multinational, real-world clinical practice, noninterventional study. PLoS One 12, e0175207

115. Nath N, Flemming R, Godat B, Urh M. (2017) Development of NanoLuc bridging immunoassay for detection of anti-drug antibodies. J. Immunol. Methods 450, 17-26

116. Van Stappen T, Vande Casteele N, Van Assche G, Ferrante M, Vermeire S, Gils A. (2018) Clinical relevance of detecting anti-infliximab antibodies with a drug-tolerant assay: post hoc analysis of the TAXIT trial. Gut $67,818-826$ 
117. Baert F. (2015) Is there a role for therapeutic drug monitoring of anti-TNF monoclonal antibodies in inflammatory bowel disease. Dig. Dis. 33, 70-77

118. Berends SE, Strik AS, Löwenberg M, D’Haens GR, Mathôt RAA. (2019) Clinical Pharmacokinetic and Pharmacodynamic Considerations in the Treatment of Ulcerative Colitis. Clin. Pharmacokinet. 58, 15-37

119. Burakoff R, Barish CF, Riff D, et al. (2006) A phase 1/2A trial of STA 5326, an oral interleukin-12/23 inhibitor, in patients with active moderate to severe Crohn's disease. Inflamm. Bowel Dis. 12, 558-565

120. Sands BE, Jacobson EW, Sylwestrowicz T, et al. (2009) Randomized, double-blind, placebocontrolled trial of the oral interleukin-12/23 inhibitor apilimod mesylate for treatment of active Crohn's disease. Inflamm. Bowel Dis. 16, 1209-1218

121. Sandborn WJ, Su C, Sands BE, et al. (2017) Tofacitinib as induction and maintenance therapy for ulcerative colitis. N. Engl. J. Med. 376, 1723-1736

122. Hampe J, Franke A, Rosenstiel P, et al. (2006) A genome-wide association scan of nonsynonymous SNPs identifies a susceptibility variant for Crohn disease in ATG16L1. Nat. Genet. 39, 207-211

123. Saitoh T, Fujita N, Jang MH, et al. (2008) Loss of the autophagy protein Atg16L1 enhances endotoxin-induced IL-1 $\beta$ production. Nature 456, 264-268

124. Zhang H-F, Qiu L-X, Chen Y, et al. (2009) ATG16L1 T300A polymorphism and Crohn's disease susceptibility: evidence from 13,022 cases and 17,532 controls. Hum. Genet. 125, 627631

125. Homer CR, Richmond AL, Rebert NA, Achkar J, McDonald C. (2010) ATG16L1 and NOD2 interact in an autophagy-dependent antibacterial pathway implicated in Crohn's disease pathogenesis. Gastroenterology 139, 1630-1641

126. Zhou X-J, Zhang H. (2012) Autophagy in immunity: implications in etiology of autoimmune/autoinflammatory diseases. Autophagy 8, 1286-1299

127. Murthy A, Li Y, Peng I, et al. (2014) A Crohn's disease variant in Atg1611 enhances its degradation by caspase 3 . Nature $506,456-462$

128. Hooper KM, Barlow PG, Stevens C, Henderson P. (2017) Inflammatory Bowel Disease Drugs: A Focus on Autophagy. J. Crohn's Colitis 11, 118-127

129. Tschurtschenthaler M, Adolph TE, Ashcroft JW, et al. (2017) Defective ATG16L1-mediated removal of IRE1 $\alpha$ drives Crohn's disease-like ileitis. J. Exp. Med. 214, 401-422 
130. Matsuzawa-Ishimoto Y, Hwang S, Cadwell K. (2018) Autophagy and inflammation. Annu. Rev. Immunol. 36, 73-101

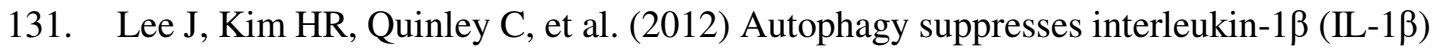
signaling by activation of p62 degradation via lysosomal and proteasomal pathways. J. Biol. Chem. 287, 4033-4040

132. Adolph TE, Tomczak MF, Niederreiter L, et al. (2013) Paneth cells as a site of origin for intestinal inflammation. Nature 503, 272

133. Lassen KG, Kuballa P, Conway KL, et al. (2014) Atg16L1 T300A variant decreases selective autophagy resulting in altered cytokine signaling and decreased antibacterial defense. Proc. Natl. Acad. Sci. 111, 7741-7746

134. Singh SB, Davis AS, Taylor GA, Deretic V. (2006) Human IRGM induces autophagy to eliminate intracellular mycobacteria. Science. 313, 1438-1441

135. Parkes M, Barrett JC, Prescott NJ, et al. (2007) Sequence variants in the autophagy gene IRGM and multiple other replicating loci contribute to Crohn's disease susceptibility. Nat. Genet. 39, 830-832

136. McCarroll SA, Huett A, Kuballa P, et al. (2008) Deletion polymorphism upstream of IRGM associated with altered IRGM expression and Crohn's disease. Nat. Genet. 40, 1107-1112

137. Brest P, Lapaquette P, Souidi M, et al. (2011) A synonymous variant in IRGM alters a binding site for miR-196 and causes deregulation of IRGM-dependent xenophagy in Crohn's disease. Nat. Genet. 43, 242-245

138. Hui KY, Fernandez-Hernandez H, Hu J, et al. (2018) Functional variants in the LRRK2 gene confer shared effects on risk for Crohn's disease and Parkinson's disease. Sci. Transl. Med. 10, eaai7795

139. Cooney R, Baker J, Brain O, et al. (2010) NOD2 stimulation induces autophagy in dendritic cells influencing bacterial handling and antigen presentation. Nat. Med. 16, 90-97

140. Lassen KG, McKenzie CI, Mari M, et al. (2016) Genetic coding variant in GPR65 alters lysosomal $\mathrm{pH}$ and links lysosomal dysfunction with colitis risk. Immunity 44, 1392-1405

141. van Beek N, Klionsky DJ, Reggiori F. (2018) Genetic aberrations in macroautophagy genes leading to diseases. Biochim. Biophys. Acta - Mol. Cell Res. 1865, 803-816

142. Levine B, Kroemer G. (2019) Biological Functions of Autophagy Genes: A Disease Perspective. Cell 176, 11-42 
143. Li B, Wang F, Schall N, Muller S. (2018) Rescue of autophagy and lysosome defects in salivary glands of MRL/lpr mice by a therapeutic phosphopeptide. J. Autoimmun. 90, 132-145

144. Levine B, Mizushima N, Virgin HW. (2011) Autophagy in immunity and inflammation. Nature 469, 323

145. Gros F, Arnold J, Page N, et al. (2012) Macroautophagy is deregulated in murine and human lupus T lymphocytes. Autophagy 8, 1113-1123

146. Pierdominici M, Vomero M, Barbati C, et al. (2012) Role of autophagy in immunity and autoimmunity, with a special focus on systemic lupus erythematosus. FASEB J. 26, 1400-1412

147. Jones SA, Mills KHG, Harris J. (2013) Autophagy and inflammatory diseases. Immunol. Cell Biol. 91, 250-258

148. Macri C, Wang F, Tasset I, et al. (2015) Modulation of deregulated chaperone-mediated autophagy by a phosphopeptide. Autophagy 11, 472-486

149. Liu X, Qin H, Xu J. (2016) The role of autophagy in the pathogenesis of systemic lupus erythematosus. Int. Immunopharmacol. 40, 351-361

150. Muller S, Brun S, René F, de Sèze J, Loeffler J-P, Jeltsch-David H. (2017) Autophagy in neuroinflammatory diseases. Autoimmun. Rev. 16, 856-874

151. Brun S, Schall N, Bonam SR, et al. (2018) An autophagy-targeting peptide to treat chronic inflammatory demyelinating polyneuropathies. J. Autoimmun. 92, 114-125

152. Page N, Gros F, Schall N, Briand J-P, Muller S. (2011) A therapeutic peptide in lupus alters autophagic processes and stability of MHCII molecules in MRL/lpr B cells. Autophagy 7, 539540

153. Baek K-H, Park J, Shin I. (2012) Autophagy-regulating small molecules and their therapeutic applications. Chem. Soc. Rev. 41, 3245-3263

154. Rubinsztein DC, Codogno P, Levine B. (2012) Autophagy modulation as a potential therapeutic target for diverse diseases. Nat. Rev. Drug Discov. 11, 709

155. Cheng Y, Ren X, Hait WN, Yang J-M. (2013) Therapeutic targeting of autophagy in disease: biology and pharmacology. Pharmacol. Rev. 65, 1162-1197

156. Gros F, Muller S. (2014) Pharmacological regulators of autophagy and their link with modulators of lupus disease. Br. J. Pharmacol. 171, 4337-4359

157. Vakifahmetoglu-Norberg H, Xia H, Yuan J. (2015) Pharmacologic agents targeting autophagy. J. Clin. Invest. 125, 5-13 
158. Galluzzi L, Bravo-San Pedro JM, Levine B, Green DR, Kroemer G. (2017) Pharmacological modulation of autophagy: therapeutic potential and persisting obstacles. Nat. Rev. Drug Discov. 16, 487

159. Kaushik S, Cuervo AM. (2018) The coming of age of chaperone-mediated autophagy. Nat. Rev. Mol. Cell Biol. 19, 365-381

160. Bhonde MR, Gupte RD, Dadarkar SD, et al. (2008) A novel mTOR inhibitor is efficacious in a murine model of colitis. Am. J. Physiol. Liver Physiol. 295, G1237-G1245

161. Mutalib M, Borrelli O, Blackstock S, et al. (2014) The use of sirolimus (rapamycin) in the management of refractory inflammatory bowel disease in children. J. Crohn's Colitis 8, 17301734

162. Macias-Ceja DC, Cosín-Roger J, Ortiz-Masiá D, et al. (2017) Stimulation of autophagy prevents intestinal mucosal inflammation and ameliorates murine colitis. Br. J. Pharmacol. $174,2501-2511$

163. Gong Z, Tasset I, Diaz A, et al. (2018) Humanin is an endogenous activator of chaperonemediated autophagy. J. Cell Biol. 217, 635-647

164. Goodwin JM, Murphy LO. (2015) Small-molecule inhibitors: bULKing up mTOR inhibition. Nat. Chem. Biol. 11, 758

165. Pasquier B. (2016) Autophagy inhibitors. Cell. Mol. life Sci. 73, 985-1001

166. Perl A. (2016) Activation of mTOR (mechanistic target of rapamycin) in rheumatic diseases. Nat. Rev. Rheumatol. 12, 169-182

167. Georgakopoulos ND, Wells G, Campanella M. (2017) The pharmacological regulation of cellular mitophagy. Nat. Chem. Biol. 13, 136-146

168. Bonam SR, Wang F, Muller S. (2018) Autophagy: A new concept in autoimmunity regulation and a novel therapeutic option. J. Autoimmun. 94, 16-32

169. Bonam SR, Wu Yuan S, Tunki L, et al. (2018) What has come out from phytomedicines and herbal edibles for the treatment of cancer? ChemMedChem 13, 1854-1872

170. Schreiber K, Davies N, Hunt BJ. (2018) Using hydroxychloroquine and protecting the retina. Lupus 27, 1399-1401

171. Li J, Kim SG, Blenis J. (2014) Rapamycin: one drug, many effects. Cell Metab. 19, 373-379

172. Kennedy BK, Lamming DW. (2016) The mechanistic target of rapamycin: the grand conducTOR of metabolism and aging. Cell Metab. 23, 990-1003 
173. Lee S-Y, Lee SH, Yang E-J, et al. (2015) Metformin ameliorates inflammatory bowel disease by suppression of the STAT3 signaling pathway and regulation of the between Th17/Treg balance. PLoS One 10, e0135858

174. Deng J, Zeng L, Lai X, et al. (2018) Metformin protects against intestinal barrier dysfunction via AMPKa1-dependent inhibition of JNK signalling activation. J. Cell. Mol. Med. 22, 546557

175. Di Fusco D, Dinallo V, Monteleone I, et al. (2018) Metformin inhibits inflammatory signals in the gut by controlling AMPK and p38 MAP kinase activation. Clin. Sci. 132, 1155-1168

176. Parent M, Boudier A, Maincent P, et al. (2016) LR12-peptide quantitation in whole blood by RP-HPLC and intrinsic fluorescence detection: Validation and pharmacokinetic study. Biomed. Chromatogr. 31, e3877

177. Kökten T, Gibot S, Lepage P, et al. (2018) TREM-1 inhibition restores impaired autophagy activity and reduces colitis in mice. J. Crohn's Colitis 12, 230-244

178. Brynjolfsson SF, Magnusson MK, Kong PL, et al. (2016) An antibody against Triggering Receptor Expressed on Myeloid Cells 1 (TREM-1) dampens proinflammatory cytokine secretion by lamina propria cells from patients with IBD. Inflamm. Bowel Dis. 22, 1803-1811

179. Shoji-Kawata S, Sumpter R, Leveno M, et al. (2013) Identification of a candidate therapeutic autophagy-inducing peptide. Nature 494, 201

180. Wong M, Leung L, Nighot PK. (2017) Role of Autophagy Related Protein ATG6/Beclin 1 in Intestinal Tight Junction Barrier. Gastroenterology 152, S119

181. Monneaux F, Lozano JM, Patarroyo ME, Briand J, Muller S. (2003) T cell recognition and therapeutic effect of a phosphorylated synthetic peptide of the 70K snRNP protein administered in MRL/lpr mice. Eur. J. Immunol. 33, 287-296

182. Page N, Schall N, Strub J-M, et al. (2009) The spliceosomal phosphopeptide P140 controls the lupus disease by interacting with the HSC70 protein and via a mechanism mediated by $\gamma \delta \mathrm{T}$ cells. PLoS One 4, e5273

183. Page N, Gros F, Schall N, et al. (2011) HSC70 blockade by the therapeutic peptide P140 affects autophagic processes and endogenous MHCII presentation in murine lupus. Ann. Rheum. Dis. 70, 837-843

184. Schall N, Page N, Macri C, Chaloin O, Briand J-P, Muller S. (2012) Peptide-based approaches to treat lupus and other autoimmune diseases. J. Autoimmun. 39, 143-153

185. Schall N, Muller S. (2015) Resetting the autoreactive immune system with a therapeutic 
peptide in lupus. Lupus 24, 412-418

186. Monneaux F, Hoebeke J, Sordet C, et al. (2005) Selective modulation of CD4+ T cells from lupus patients by a promiscuous, protective peptide analog. J. Immunol. 175, 5839-5847

187. Monneaux F, Parietti V, Briand J-P, Muller S. (2007) Importance of spliceosomal RNP1 motif for intermolecular TB cell spreading and tolerance restoration in lupus. Arthritis Res. Ther. 9, R111

188. Muller S, Monneaux F, Schall N, et al. (2008) Spliceosomal peptide P140 for immunotherapy of systemic lupus erythematosus: results of an early phase II clinical trial. Arthritis Rheum. 58, 3873-3883

189. Zimmer R, Scherbarth HR, Rillo OL, Gomez-Reino JJ, Muller S. (2013) Lupuzor/P140 peptide in patients with systemic lupus erythematosus: a randomised, double-blind, placebocontrolled phase IIb clinical trial. Ann. Rheum. Dis. 72, 1830-1835

190. Wilhelm M, Wang F, Schall N, et al. (2018) Lupus regulator peptide P140 represses B cell differentiation by reducing HLA class II molecule overexpression. Arthritis Rheumatol. 70, $1077-1088$

191. Stricher F, Macri C, Ruff M, Muller S. (2013) HSPA8/HSC70 chaperone protein: structure, function, and chemical targeting. Autophagy 9, 1937-1954

192. Wang F, Bonam SR, Schall N, et al. (2018) Blocking nuclear export of HSPA8 after heat shock stress severely alters cell survival. Sci. Rep. 8, 16820

193. Liu W-T, Lin C-H, Hsiao M, Gean P-W. (2011) Minocycline inhibits the growth of glioma by inducing autophagy. Autophagy 7, 166-175

194. Yin H, Wu H, Chen Y, et al. (2018) The therapeutic and pathogenic role of autophagy in autoimmune diseases. Front. Immunol. 9, 1512

195. Galluzzi L, Baehrecke EH, Ballabio A, et al. (2017) Molecular definitions of autophagy and related processes. EMBO J. 36, 1811-1836

196. Reggiori F, Ungermann C. (2017) Autophagosome maturation and fusion. J. Mol. Biol. 429, 486-496

197. Kawalec P, Mikrut A, Wiśniewska N, Pilc A. (2013) Tumor necrosis factor- $\alpha$ antibodies (infliximab, adalimumab and certolizumab) in Crohn's disease: systematic review and metaanalysis. Arch. Med. Sci. 9, 765-779

198. Mitoma H, Horiuchi T, Tsukamoto H, Ueda N. (2018) Molecular mechanisms of action of 
anti-TNF- $\alpha$ agents - Comparison among therapeutic TNF- $\alpha$ antagonists. Cytokine 101, 56-63

981

982

983

984

985

986

987

199. Kim S, Eun HS, Jo E-K. (2019) Roles of Autophagy-Related Genes in the Pathogenesis of Inflammatory Bowel Disease. Cells 8, 77

200. Corremans R, Vervaet BA, D’Haese PC, Neven E, Verhulst A. (2018) Metformin: A Candidate Drug for Renal Diseases. Int. J. Mol. Sci. 20, 42

201. Deng J, Peng M, Wang Z, et al. (2019) Novel application of metformin combined with targeted drugs on anticancer treatment. Cancer Sci. 110, 23-30

202. Florez JC. (2017) The pharmacogenetics of metformin. Diabetologia 60, 1648-1655 

drugs and compounds under development commonly target two large areas of regulation, namely inhibition of cytokine signalling pathways (left) and inhibition of leukocyte trafficking to the gut mucosa (right). The target of therapeutic antibodies (green) and small molecules (violet) are shown. Most if not all of these regulating compounds are inhibiting/blocking agents. Abbreviations: $\alpha 4 \beta 1 / 7$, integrin alpha 4 beta 1/7; IL, interleukin; JAK, Janus kinase; TYK, tyrosine kinase; MadCCAM1, mucosal addressin cell adhesion molecule 1; TGF- $\beta$, transforming growth factor beta; TNF, tumor necrosis factor; S1P-R, sphingosine-1-phosphate receptor; SMAD7, mothers against decapentaplegic homolog 7.

998

Figure 2: Signalling pathways that control the macroautophagy machinery and sites of action of past and novel autophagy-regulating pharmacological tools. Autophagy can be activated by inhibitors of MTOR (rapamycin, torin1, P2281, niclosamide, temsirolimus/CCI779), AKT (perifosine), TREM-1 (LR12 peptide) as well as by activation of AMPK (metformin, minocycline, trehalose). Inhibitors of autophagy include PI3K inhibitors (3-MA, wortmannin, LY294002, SAR405, VPS34-IN1, spautin, PT21, CH5132799, GDC-0941), initiation inhibitors (MRT67307, MRT68921, SBI-0206965, NSC185058, edaravone, cardiac glycosides), a phagophore elongation inhibitor mdivi-1 and autophagosome-lysosome fusion inhibitors (e.g. bafilomycin A, vinblastine, nocodazole, monensin). The final degradation step of autophagy can also be inhibited by compounds such as HCQ, CQ, bafilomycin A, lys05, leupeptin, pepstatin, E64d, mefloquine, and $\mathrm{NH}_{4} \mathrm{Cl}$. In lupus, administration of $\mathrm{P} 140$ peptide significantly decreases the overexpression of LAMP2A and HSPA8, which are key factors of CMA. Abbreviations not used in the text: 3-MA, methyladenine; Mdivi-1, mitochondrial division inhibitor. P2281, LY294002, Lys05, SAR405, VPS34-IN1, PT21, CH5132799, GDC-0941 MRT67307, MRT68921, NSC185058, SBI-0206965, NSC185058 are compound codes used in the literature.

Figure 3: The role of autophagy in the pathogenesis of IBDs. Genetic predispositions in autophagy-related genes (ATG16L1, IRGM, LRRK2, NOD2/CARD15) are largely reported in IBDs. Upon environmental triggers, such as pathogens and unhealthy diet, defects in multiple steps of autophagy may lead to altered functions of the intestinal barrier and abnormal intestinal immune responses, which can collectively manifest as IBDs. Abbreviations: TJ, tight junctions; APC, Antigen-presenting cells; ER, endoplasmatic reticulum. 
Table 1: Therapeutic strategies currently approved and/or in current use for the treatment of IBDs

\begin{tabular}{|c|c|c|c|c|c|c|}
\hline \multicolumn{2}{|l|}{ Drug } & $\begin{array}{l}\text { Mechanism of } \\
\text { action /target }\end{array}$ & $\begin{array}{l}\text { Efficacy } \\
\text { (significant } \\
\text { results) }\end{array}$ & $\begin{array}{l}\text { Serious Adverse } \\
\text { Effects }\end{array}$ & $\begin{array}{l}\text { Clinical } \\
\text { status }\end{array}$ & Refs. \\
\hline \multicolumn{7}{|c|}{ Small molecules (corticoids and immunosuppressants) } \\
\hline \multicolumn{2}{|c|}{$\begin{array}{l}\text { Amino salicylates } \\
\text { (sulfasalazine, } \\
\text { mesalazine, } 4- \\
\text { aminosalicylic acid, } \\
\text { balsalazide, olsalazine) }\end{array}$} & $\begin{array}{l}\text { Free radical } \\
\text { scavengers, 5- } \\
\text { lipoxygenase } \\
\text { inhibition, effects } \\
\text { on leucocyte } \\
\text { function and } \\
\text { production of } \\
\text { cytokines }\end{array}$ & $\begin{array}{l}\text { Clinical } \\
\text { remission rates } \\
\text { of } 40-70 \% \text { have } \\
\text { been reported } \\
\text { with mesalazine } \\
\text { over 6-8 } \\
\text { weeks in UC }\end{array}$ & $\begin{array}{l}\text { Nephrotoxicity, } \\
\text { agranulocytosis, } \\
\text { alveolitis, } \\
\text { pancreatitis, } \\
\text { abdominal pain, } \\
\text { flatulence, nausea, } \\
\text { dyspepsia }\end{array}$ & $\begin{array}{l}\text { Common } \\
\text { use }\end{array}$ & {$[57,59]$} \\
\hline \multicolumn{2}{|c|}{$\begin{array}{l}\text { Prednisone, 6- } \\
\text { methylprednisolone, } \\
\text { budesonide MMX }\end{array}$} & $\begin{array}{l}\text { Binds to high } \\
\text { affinity } \\
\text { intracellular } \\
\text { cytoplasmic } \\
\text { receptors }\end{array}$ & $\begin{array}{l}\text { Clinical } \\
\text { remission at } 8 \\
\text { weeks (17.4\%- } \\
\text { Budesonide } \\
\text { MMX } 9 \text { mg vs. } \\
4.5 \% \text {-placebo) } \\
\text { in UC }\end{array}$ & $\begin{array}{l}\text { Diabetes, } \\
\text { osteoporosis, moon } \\
\text { face, and acne, } \\
\text { growth retardation } \\
\text { in children, } \\
\text { psychosis, hepatic } \\
\text { seatosis }\end{array}$ & $\begin{array}{l}\text { Common } \\
\text { use }\end{array}$ & $\begin{array}{l}{[47,48,} \\
68,70]\end{array}$ \\
\hline \multicolumn{2}{|c|}{$\begin{array}{l}\text { Thiopurines } \\
\text { (6-mercaptopurine, } \\
\text { azathioprine) }\end{array}$} & $\begin{array}{l}\text { Incorporates into } \\
\text { nucleotides }\end{array}$ & $\begin{array}{l}\text { Maintain } \\
\text { remission in } \\
\text { moderate to } \\
\text { severe } \mathrm{CD} / \mathrm{UC}\end{array}$ & $\begin{array}{l}\text { Myelosuppression, } \\
\text { non-Hodgkin } \\
\text { lymphoma }\end{array}$ & $\begin{array}{l}\text { Common } \\
\text { use }\end{array}$ & {$[61]$} \\
\hline \multicolumn{2}{|c|}{ Methotrexate } & $\begin{array}{l}\text { Inhibits enzymes in } \\
\text { folic acid metabolic } \\
\text { pathway (for high } \\
\text { doses used in } \\
\text { oncology/ } \\
\text { hematology; mode } \\
\text { of action is } \\
\text { unknown for low } \\
\text { doses used in CD) }\end{array}$ & $\begin{array}{l}\text { Clinical } \\
\text { remission at } 16 \\
\text { weeks }(39 \%-25 \\
\text { mg vs. } 19 \%- \\
\text { placebo; } 65 \%- \\
15 \text { mg vs. } 39 \%) \\
\text { in CD }\end{array}$ & $\begin{array}{l}\text { Dyspnoea, nausea, } \\
\text { vomiting, and } \\
\text { neutropenia }\end{array}$ & $\begin{array}{l}\text { Common } \\
\text { use }\end{array}$ & {$[63,64]$} \\
\hline \multicolumn{2}{|c|}{ Cyclosporine } & $\begin{array}{l}\text { Calcineurin } \\
\text { inhibitor }\end{array}$ & $\begin{array}{l}\text { Cyclosporine ( } 4 \\
\mathrm{mg} / \mathrm{kg}) \text { showed } \\
82 \% \text { response } \\
\text { rate vs. placebo } \\
(\mathrm{P}<0.001) \text { in } 7 \\
\text { days in UC }\end{array}$ & $\begin{array}{l}\text { Renal failure, } \\
\text { bacterial } \\
\text { pneumonia, } \\
\text { Pneumocystis } \\
\text { jiroveci pneumonia, } \\
\text { venous catheter } \\
\text { infections }\end{array}$ & $\begin{array}{l}\text { Common } \\
\text { use }\end{array}$ & [46] \\
\hline \multicolumn{2}{|l|}{ Tacrolimus } & $\begin{array}{l}\text { Calcineurin } \\
\text { inhibitor }\end{array}$ & $\begin{array}{l}\text { Clinical } \\
\text { remission at } 2 \\
\text { weeks }(9.4 \% \text { vs. } \\
0.0 \% \text {-placebo) } \\
\text { in UC }\end{array}$ & $\begin{array}{l}\text { Tremor, } \\
\text { paraesthesia, } \\
\text { insomnia, hot flush, } \\
\text { alopecia, } \\
\text { hyperglycaemia, } \\
\text { hypomagnesaemia, } \\
\text { hypertension, } \\
\text { hepatotoxicity, } \\
\text { nephrotoxicity }\end{array}$ & $\begin{array}{l}\text { Common } \\
\text { use }\end{array}$ & {$[56]$} \\
\hline \multicolumn{7}{|c|}{ Therapeutic antibodies } \\
\hline $\begin{array}{l}\text { Generic } \\
\text { name }\end{array}$ & $\begin{array}{l}\text { Trade } \\
\text { name/ } \\
\text { synonym }\end{array}$ & & & & & \\
\hline Infliximab & Remicade & TNF- $\alpha$ antagonist & $\begin{array}{l}\text { Clinical } \\
\text { remission at } 30 \\
\text { weeks }(35.8 \%- \\
10 \mathrm{mg} \text { vs. }\end{array}$ & $\begin{array}{l}\text { Drug-induced } \\
\text { lupus, infusion } \\
\text { reactions, } \\
\text { hypersensitivity }\end{array}$ & $\begin{array}{l}\text { Approved by } \\
\text { FDA since } \\
2007 \text { for } \\
\text { CD/UC }\end{array}$ & {$[49,65]$} \\
\hline
\end{tabular}




\begin{tabular}{|c|c|c|c|c|c|c|}
\hline & & & $\begin{array}{l}15.7 \% \text {-placebo) } \\
\text { in UC. } \\
\text { Clinical } \\
\text { remission at } 10 \\
\text { weeks } \\
(57.5 \%) \text { in CD }\end{array}$ & $\begin{array}{l}\text { reactions, } \\
\text { demyelination, } \\
\text { reactivation of } \\
\text { latent tuberculosis, } \\
\text { Non-Hodgkin's } \\
\text { lymphoma }\end{array}$ & & \\
\hline $\begin{array}{l}\text { Adalimum } \\
\mathrm{ab}\end{array}$ & Humira & TNF- $\alpha$ & $\begin{array}{l}\text { Clinical } \\
\text { remission at } \\
\text { week } 56(36 \%- \\
400 \mathrm{mg} \text { eow, } \\
41 \%-400 \mathrm{mg} \\
\text { weekly, vs. } \\
12 \% \text {-placebo }) \text { in } \\
\text { CD }\end{array}$ & $\begin{array}{l}\text { Congestive heart } \\
\text { failure, lupus-like } \\
\text { syndrome, } \\
\text { lymphoma, } \\
\text { cytopenia, multiple } \\
\text { sclerosis/neurologic } \\
\text { al disease, } \\
\text { pancytopenia }\end{array}$ & $\begin{array}{l}\text { Approved by } \\
\text { FDA since } \\
2007 \text { for } \\
\text { CD/UC }\end{array}$ & {$[62]$} \\
\hline $\begin{array}{l}\text { Certolizu } \\
\text { mab Pegol }\end{array}$ & Cimzia & TNF- $\alpha$ & $\begin{array}{l}\text { Clinical } \\
\text { response at } 10 \\
\text { weeks ( } 52.8 \% \text { - } \\
400 \mathrm{mg} \text { vs. } \\
30.1 \% \text { - placebo) } \\
\text { in CD }\end{array}$ & $\begin{array}{l}\text { Injection site } \\
\text { reaction, infections, } \\
\text { lupus-like } \\
\text { syndrome }\end{array}$ & $\begin{array}{l}\text { Approved by } \\
\text { FDA since } \\
2008 \text { for CD }\end{array}$ & $\begin{array}{l}{[50,51,} \\
54]\end{array}$ \\
\hline $\begin{array}{l}\text { Golimuma } \\
\text { b }\end{array}$ & Symponi & TNF- $\alpha$ & $\begin{array}{l}\text { Clinical } \\
\text { remission at } 54 \\
\text { weeks }(27.8 \% \text { - } \\
100 \mathrm{mg} \text { vs. } \\
15.6 \% \text {-placebo) } \\
\text { in UC }\end{array}$ & $\begin{array}{l}\text { Erythema, } \\
\text { tuberculosis, rectal, } \\
\text { thyroid, and lung } \\
\text { adenocarcinoma }\end{array}$ & $\begin{array}{l}\text { Approved by } \\
\text { FDA and } \\
\text { EMA since } \\
2003 \text { for UC }\end{array}$ & {$[69,72]$} \\
\hline $\begin{array}{l}\text { Ustekinum } \\
\mathrm{ab}\end{array}$ & Stelara & IL-12/ IL-23 & $\begin{array}{l}\text { Clinical } \\
\text { remission at } 44 \\
\text { weeks (53.1\%- } \\
90 \text { mg every } 8 \\
\text { weeks and } \\
48.8 \%-90 \mathrm{mg} \\
\text { every } 12 \text { weeks } \\
\text { vs. } 35.9 \% \text { - } \\
\text { placebo) in CD }\end{array}$ & $\begin{array}{l}\text { Nasopharyngitis } \\
\text { upper respiratory } \\
\text { tract infections, } \\
\text { diverticulitis, } \\
\text { cellulitis, } \\
\text { pneumonia }\end{array}$ & $\begin{array}{l}\text { Approved by } \\
\text { FDA since } \\
2016 \text { for CD }\end{array}$ & $\begin{array}{l}{[53,58,} \\
66,71]\end{array}$ \\
\hline $\begin{array}{l}\text { Natalizum } \\
\text { ab }\end{array}$ & Tysabri & $\alpha 4$ integrin & $\begin{array}{l}\text { Clinical } \\
\text { remission at } 8 \\
\text { weeks ( } 26 \%- \\
300 \mathrm{mg} \text { vs. } \\
16 \% \text {-placebo) in } \\
\mathrm{CD}\end{array}$ & $\begin{array}{l}\text { Pharyngitis, urinary } \\
\text { tract infection, } \\
\text { urticaria, cephalgia, } \\
\text { arthralgia, PML }\end{array}$ & $\begin{array}{l}\text { Approved by } \\
\text { FDA since } \\
2004 \text { for CD }\end{array}$ & {$[52]$} \\
\hline $\begin{array}{l}\text { Vedolizu } \\
\text { mab }\end{array}$ & Entyvio & $\alpha 4 ß 7$ integrin & $\begin{array}{l}\text { Clinical } \\
\text { remission at } 52 \\
\text { weeks ( } 44.8 \%- \\
300 \mathrm{mg} \text { vs. } \\
29.1 \% \text {-placebo) } \\
\text { in CD }\end{array}$ & $\begin{array}{l}\text { Gastrointestinal and } \\
\text { respiratory tract } \\
\text { infections, hepatic } \\
\text { steatosis }\end{array}$ & $\begin{array}{l}\text { Approved by } \\
\text { FDA since } \\
2014 \text { for } \\
\text { CD/UC }\end{array}$ & $\begin{array}{l}{[55,60,} \\
67]\end{array}$ \\
\hline \multicolumn{7}{|c|}{ Other small molecules } \\
\hline $\begin{array}{l}\text { Tofacitini } \\
\text { b }\end{array}$ & Xeljanz & Pan-JAK inhibitor & $\begin{array}{l}\text { Clinical } \\
\text { remission at } 8 \\
\text { weeks ( } 18.5 \% \text { - } \\
10 \mathrm{mg} \text { vs } 8.2 \% \text { - } \\
\text { placebo) in UC }\end{array}$ & $\begin{array}{l}\text { Herpes zoster } \\
\text { infection, upper } \\
\text { respiratory tract } \\
\text { infections, } \\
\text { headache, diarrhea, } \\
\text { nasopharyngitis }\end{array}$ & $\begin{array}{l}\text { Approved by } \\
\text { FDA since } \\
2018 \text { for UC }\end{array}$ & {$[121]$} \\
\hline
\end{tabular}


Table 2: Therapeutic strategies currently under clinical evaluation for IBDs

\begin{tabular}{|c|c|c|c|c|c|c|}
\hline \multicolumn{2}{|l|}{ Drugs } & \multirow{2}{*}{$\begin{array}{l}\text { Mechanism } \\
\text { of action } \\
\text { /target }\end{array}$} & \multirow{2}{*}{$\begin{array}{l}\text { Efficacy } \\
\text { (significant } \\
\text { results) }\end{array}$} & \multirow{2}{*}{$\begin{array}{l}\text { Serious Adverse } \\
\text { Effects }\end{array}$} & \multirow{2}{*}{$\begin{array}{l}\text { Clinical } \\
\text { status }\end{array}$} & \multirow[t]{2}{*}{ Refs. } \\
\hline Generic name & $\begin{array}{l}\text { Trade } \\
\text { name/ } \\
\text { synonym }\end{array}$ & & & & & \\
\hline \multicolumn{7}{|c|}{ Therapeutic antibodies } \\
\hline Golimumab & Symponi & TNF- $\alpha$ & $\begin{array}{l}\text { Retrospective } \\
\text { analysis in } \\
115 \mathrm{CD} \\
\text { patients: } \\
\text { Clinical } \\
\text { response } \\
55.8 \% \text { in } 4 \\
\text { months }\end{array}$ & $\begin{array}{l}\text { Infections, drug- } \\
\text { induced lupus }\end{array}$ & $\begin{array}{l}\text { No formal } \\
\text { trials have } \\
\text { been done } \\
\text { for CD }\end{array}$ & {$[72,95]$} \\
\hline Risankizumab & $\begin{array}{l}\text { BI-655066 } \\
\text { or } \\
\text { ABBV-066 }\end{array}$ & IL-23(p19) & $\begin{array}{l}\text { Clinical } \\
\text { remission at } \\
12 \text { weeks } \\
(31 \% \text { vs. } \\
15 \% \text {-placebo) } \\
\text { in CD }\end{array}$ & $\begin{array}{l}\text { Nausea, } \\
\text { worsening of } \\
\text { underlying CD }\end{array}$ & $\begin{array}{l}\text { Phase III } \\
\text { trials for } \\
\text { CD }\end{array}$ & [94] \\
\hline Brazikumab & $\begin{array}{l}\text { AMG } 139 \\
\text { or } \\
\text { MEDI } 2070\end{array}$ & IL-23(p19) & $\begin{array}{l}\text { Clinical } \\
\text { remission at } 8 \\
\text { weeks }(49.2 \% \\
\text { vs. } 26.7 \% \text { - } \\
\text { placebo) in } \\
\text { CD }\end{array}$ & $\begin{array}{l}\text { Headache, } \\
\text { nasopharyngitis }\end{array}$ & $\begin{array}{l}\text { Phase II } \\
\text { trials for } \\
\text { CD }\end{array}$ & [99] \\
\hline Briakinumab & ABT-874 & $\begin{array}{l}\text { IL- } \\
\text { 12/23(p40) }\end{array}$ & $\begin{array}{l}\text { Clinical } \\
\text { remission at } \\
24 \text { weeks } \\
(48 \%-400 \mathrm{mg} \text {, } \\
57 \%-700 \mathrm{mg} \\
\text { vs. } 29 \%- \\
\text { placebo) in } \\
\mathrm{CD}\end{array}$ & $\begin{array}{l}\text { Respiratory tract } \\
\text { infection, nausea, } \\
\text { abdominal pain, } \\
\text { headache, } \\
\text { cardiovascular } \\
\text { events }\end{array}$ & $\begin{array}{l}\text { Phase II } \\
\text { trials for } \\
\text { CD }\end{array}$ & {$[85,90]$} \\
\hline Mirikizumab & LY3074828 & IL-23 (p19) & $\begin{array}{l}\text { Clinical } \\
\text { remission at } \\
12 \text { weeks } \\
\text { ( } 31 \% \text { vs. } \\
4.8 \%- \\
\text { placebo) in } \\
\text { UC }\end{array}$ & $\begin{array}{l}\text { No SAEs } \\
\text { reported }\end{array}$ & $\begin{array}{l}\text { Phase II } \\
\text { trials for } \\
\text { CD/UC }\end{array}$ & [103] \\
\hline \multirow[t]{2}{*}{ Etrolizumab } & rhuMAb $\beta 7$ & $\begin{array}{l}\beta 7 \text { subunit of } \\
\text { integrins } \\
\alpha 4 \beta 7 \text { and } \\
\alpha \mathrm{E} \beta 7\end{array}$ & $\begin{array}{l}\text { Clinical } \\
\text { remission at } \\
10 \text { weeks } \\
(21 \%-100 \mathrm{mg} \\
\text { vs. } 10 \%- \\
\text { placebo }) \text { in } \\
\text { CD }\end{array}$ & $\begin{array}{l}\text { Exacerbation of } \\
\text { UC, headache, } \\
\text { fatigue, } \\
\text { abdominal pain, } \\
\text { dizziness, } \\
\text { nasopharyngitis, } \\
\text { nausea, } \\
\text { arthralgia, urinary } \\
\text { tract infection }\end{array}$ & $\begin{array}{l}\text { Phase III } \\
\text { trials for } \\
\text { CD/UC }\end{array}$ & {$[88,92]$} \\
\hline & $\begin{array}{l}\text { PF- } \\
00547659\end{array}$ & MAdCAM-1 & $\begin{array}{l}\text { Clinical } \\
\text { remission at } \\
12 \text { weeks } \\
(16.7 \%-22.5 \\
\text { mg vs. } 2.7 \%- \\
\text { placebo }) \text { in } \\
\text { CD }\end{array}$ & $\begin{array}{l}\text { No SAEs } \\
\text { reported }\end{array}$ & $\begin{array}{l}\text { Phase II } \\
\text { trials for } \\
\text { CD/UC }\end{array}$ & {$[98,101]$} \\
\hline Abrilumab & AMG181 & $\alpha 4 \beta 7$ integrin & Clinical & Upper respiratory & Phase II & [87] \\
\hline
\end{tabular}




\begin{tabular}{|c|c|c|c|c|c|c|}
\hline & & & $\begin{array}{l}\text { remission at } \\
12 \text { weeks } \\
(30.8 \%-210 \\
\text { mg vs. } \\
17.6 \%- \\
\text { placebo) in } \\
\text { CD }\end{array}$ & $\begin{array}{l}\text { tract infection, } \\
\text { headache }\end{array}$ & $\begin{array}{l}\text { trials for } \\
\text { CD/UC }\end{array}$ & \\
\hline \multicolumn{7}{|c|}{ Small molecules } \\
\hline Filgotinib & GLPG0634 & JAK-1 & $\begin{array}{l}\text { Clinical } \\
\text { remission at } \\
10 \text { weeks } \\
\text { ( } 47 \% \text { vs. } \\
23 \% \text {-placebo) } \\
\text { in CD }\end{array}$ & $\begin{array}{l}\text { No SAEs } \\
\text { reported }\end{array}$ & $\begin{array}{l}\text { Phase III } \\
\text { trials for } \\
\mathrm{CD} / \mathrm{UC}\end{array}$ & {$[100]$} \\
\hline Upadacitinib & ABT-494 & JAK1 & $\begin{array}{l}\text { Clinical } \\
\text { remission at } \\
16 \text { weeks } \\
(27 \%-6 \mathrm{mg} \\
\text { vs. } 11 \%- \\
\text { placebo) in } \\
\text { CD }\end{array}$ & $\begin{array}{l}\text { Headache, non- } \\
\text { melanoma skin } \\
\text { cancer }\end{array}$ & $\begin{array}{l}\text { Phase II } \\
\text { trials for } \\
\text { CD/UC }\end{array}$ & [97] \\
\hline Ozanimod & RPC1063 & $\begin{array}{l}\text { sphingosine- } \\
\text { 1-phosphate } \\
\text { receptor }\end{array}$ & $\begin{array}{l}\text { Clinical } \\
\text { remission at } \\
32 \text { weeks } \\
(21 \%-1 \mathrm{mg}, \\
26 \%-0.5 \mathrm{mg} \\
\text { vs } 6 \%- \\
\text { placebo) in } \\
\text { UC }\end{array}$ & $\begin{array}{l}\text { Headache, } \\
\text { anemia, } \\
\text { nasopharyngitis, } \\
\text { urinary-tract } \\
\text { infections }\end{array}$ & $\begin{array}{l}\text { Phase III } \\
\text { trials for } \\
\text { UC }\end{array}$ & [96] \\
\hline \multirow[t]{2}{*}{ Mongersen } & GED 0301 & TGF- $\beta 1$ & $\begin{array}{l}\text { Clinical } \\
\text { remission at } \\
\text { day } 15(55 \%- \\
40 \mathrm{mg}, 65 \%- \\
160 \mathrm{mg} \text { vs } \\
10 \% \text {-placebo }) \\
\text { in CD }\end{array}$ & $\begin{array}{l}\text { No SAEs } \\
\text { reported }\end{array}$ & $\begin{array}{l}\text { withdrawn } \\
\text { after } \\
\text { interim } \\
\text { analysis } \\
\text { of a phase } \\
\text { III trial for } \\
\text { CD }\end{array}$ & {$[89,102]$} \\
\hline & AJM300 & $\alpha 4$ integrin & $\begin{array}{l}\text { Clinical } \\
\text { remission at } 8 \\
\text { weeks } \\
(23.5 \%-960 \\
\text { mg vs. } 3.9 \%- \\
\text { placebo }) \text { in } \\
\text { UC }\end{array}$ & $\begin{array}{l}\text { Potential risk of } \\
\text { PML }\end{array}$ & $\begin{array}{l}\text { Phase III } \\
\text { trials for } \\
\text { UC }\end{array}$ & [91] \\
\hline \multirow[t]{2}{*}{ Laquinimod } & $\begin{array}{l}\text { ABR-215062 } \\
\text { or TV-5600 }\end{array}$ & $\begin{array}{l}\text { Inhibitory } \\
\text { effect on } \\
\text { antigen } \\
\text { presenting } \\
\text { cells and T } \\
\text { cells }\end{array}$ & $\begin{array}{l}\text { Clinical } \\
\text { remission at } 8 \\
\text { weeks } \\
(48.3 \%-0.5 \\
\text { mg vs. } \\
15.9 \%- \\
\text { placebo) in } \\
\text { CD }\end{array}$ & $\begin{array}{l}\text { Headache, CD } \\
\text { exacerbation }\end{array}$ & $\begin{array}{l}\text { Phase II } \\
\text { trials for } \\
\text { CD }\end{array}$ & [86] \\
\hline & $\mathrm{ABX} 464$ & $\begin{array}{l}\text { Triggers IL- } \\
22 \text { secretion } \\
\text { in } \\
\text { macrophages }\end{array}$ & $\begin{array}{l}50 \mathrm{mg} \text {, daily } \\
\text { for } 2 \text { months, } \\
\text { clinical } \\
\text { remission } \\
35 \% \text { vs } 11 \% \\
\text { placebo in UC }\end{array}$ & $\begin{array}{l}\text { Headaches, } \\
\text { nausea and } \\
\text { vomiting (not } \\
\text { considered as } \\
\text { treatment- } \\
\text { limiting effects) }\end{array}$ & $\begin{array}{l}\text { Phase II } \\
\text { trial for } \\
\text { UC }\end{array}$ & [93] \\
\hline
\end{tabular}

Abbreviations not used in the text: vs., versus. 
1027

1028

1029

1030

1031

1032

1033

1034

1035

1036

1037

1038

1039

1040

1041

1042

1043

1044

1045

1046

1047

1048

1049

1050

1051

1052

1053

1054

1055

1056

1057

Autophagy is a vital cellular process in which a cytoplasmic cargo is delivered to lysosomes for degradation and recycling. This evolutionary-conserved intracellular pathway is finelyregulated by a large family of genes [195,196]. It continuously clears unnecessary or dysfunctional cellular components (damaged organelles, abnormally folded proteins or proteins produced in excess). Autophagy is crucial for cell adaptation to the environment and maintenance of cell homeostasis, especially under stress conditions (nutrient deprivation, hypoxia, oxidative stress, changes of intracellular level of calcium). Three main forms of autophagy have been described: macroautophagy, microautophagy and chaperonemediated autophagy (CMA). Besides these defined types, other forms of selective autophagy are operating, e.g., mitophagy, that selectively disrupts damaged mitochondria by autolysosomal degradation, xenophagy and others [195]. One of the major mechanisms by which autophagy affects the pathogenesis of IBDs is the regulation of pathogen clearance. Autophagy in Paneth cells, macrophages, and goblet cells in the intestinal wall targets invading pathogens for degradation or helps in secretion of antimicrobial peptides. In addition to pathogen clearance, autophagy plays a critical role in adaptive immune response through MHC class II-dependent antigen presentation, as substrates of autophagy can be loaded onto MHC. Mice lacking ATG5 in thymic epithelium develop severe colitis implicating the requirement of autophagy in adaptive immune response in protection against IBDs $[123,124]$.

Macroautophagy: In this canonical autophagy process, which is highly geneticallycontrolled, a double-membrane sequestering compartment termed "phagophore" is formed and expands in encapsulating cytoplasmic cargos. The resulting sealed, double-membrane vacuoles termed "autophagosomes," subsequently fuse with hydrolytic enzyme-rich lysosomes to form vacuoles called "autolysosomes" in which the cellular cargos that have been engulfed are degraded. The resulting compounds that are cleaved by hydrolases are released back into the cytosol for reuse (recycling).

Microautophagy: This dynamic form of autophagy is characterized by direct engulfment of cytoplasmic cargos in lytic organelles (lysosomes in mammals and vacuoles in plants and fungi).

Chaperone-mediated autophagy: CMA is a selective form of autophagy that, in contrast to macroautophagy and microautophagy, does not involve vesicles, but instead implicates 
chaperone proteins to directly target specific proteins to the lumen of lysosomes. CMAtargeted cargos are soluble cytoplasmic proteins, which contain a KFERQ-related pentapeptide motif that is recognised by HSPA8. Once docked on the outside of the lysosomal membrane, the targeted protein begins to unfold before it is internalized into the lysosomal lumen with the help of other chaperone and co-chaperones, including lysosomal HSPA8 and HSP90 proteins. LAMP2A plays a crucial role in the translocation process. Proteases and hydrolases that optimally function at low $\mathrm{pH}$ in the lysosome lumen degrade the selected unfolded cargo and recycle critical amino acid residues.

Xenophagy: This selective autophagy process is used to eliminate invading pathogens. Intracellular pathogens that are either inside the cytosol or in pathogen-containing vacuoles are surrounded by isolation membranes, engulfed into autophagosomes, and degraded inside autolysosomes.

\section{Box 2: Mechanisms of action of anti-TNF antibodies}

The mechanism of action of anti-TNF Abs can be many, including simple neutralisation of TNF- $\alpha$ ligand, modulation of the immune system, outside-to-inside signalling and the induction of direct or indirect apoptosis [197,198] (and references in Table 1). Infliximab, which was the first anti-TNF- $\alpha$ mAb reported to be successful for the treatment of IBDs in 1993, binds with high affinity to soluble and transmembrane TNF- $\alpha$ but not to lymphotoxin- $\alpha$ (also called TNF- $\beta$ ). Adalimumab neutralizes the activity of TNF- $\alpha$ by inhibiting its interaction with p55 and p75 cell surface TNF- $\alpha$ receptors. Its clinical efficacy was proven for maintaining remission in moderate to severe CD through 56 weeks. Its safety and efficiency were also demonstrated in patients with secondary loss of response. As infliximab and adalimumab, certolizumab pegol binds and neutralises TNF- $\alpha$. However, thanks to the fact that it does not contain an Fc region, an important structural difference with regard to infliximab and adalimumab, certolizumab pegol does not mediate complement-dependent cytotoxicity and Ab-dependent cell-mediated cytotoxicity and hence emerges as an attractive alternative anti-TNF drug. Although observed in a small proportion of patients, anti-TNF therapy displays wide-ranging effects on the immune system resulting in a spectrum of potential adverse events. Many efforts are developed to minimize these complications $[80,81,83]$.

\section{Box 3: ATG16L1, an autophagy-related gene that is associated with IBDs risk}


ATG16L1 is an essential component of autophagy [199]. It undergoes self-multimerization and forms a heterocomplex with ATG5 and ATG12, which acts as a scaffold to MAP1LC3 for lipidation. Among the nine genetic variants of ATG16L1 that have been associated to CD, the variant rs2241880, comprising a missense mutation resulting in threonine to alanine substitution at the amino acid position 300 has been associated to an increased risk to develop the disease. The $\mathrm{T}^{300} \mathrm{~A}$ mutation is located in the cleavage site of caspase 3 , and this mutation enhances the degradation of ATG16L1 by caspase 3, and hence diminishes autophagy. Loss of function of ATG16L1 inhibits autophagy in intestinal Paneth cells, resulting in a decreased production of antimicrobial peptides. Besides, ATG16L1 risk variants are defective in the generation of MHCII antigen-specific $\mathrm{CD}^{+}{ }^{+} \mathrm{T}$ cell responses in DCs.

\section{Box 4: Metformin, a molecule that displays pleiotropic effect on autophagy}

1100

1101

Metformin (or 1,1-dimethyl biguanide) is a drug which is widely given to patients with type 2 diabetes. Recent investigations led to the discovery that this synthetic derivative of guanidine displays a larger spectrum of properties than expected and could, therefore, be advantageously used in other indications, as notably autoimmune diseases, certain cancers (breast, ovarian, glioblastoma), and in aging [200,201]. Metformin is an inducer of autophagy that acts in an AMP-activated protein kinase (AMPK)-dependent manner, which phosphorylates the Unc-51 like autophagy activating kinase-1 (ULK-1/ATG1) and BECLIN 1. Metformin interacts with several receptor molecules and, directly or indirectly, interferes with several cellular pathways that are vital in cell metabolism and regulation, notably in immune cells. The mitochondrial respiratory-chain complex 1 (OCT1) is presented as the primary target of metformin [202]. The preferential action of metformin in hepatocytes is due to the predominant expression of OCT1, which has been shown to facilitate cellular uptake of metformin. It seems that metformin does not directly target AMPK but would activate AMPK in a process that would be secondary to its effect on the mitochondria, the primary target of the drug. Regarding the effect of metformin on insulin receptor, it was found that it could act through the inhibition of PTP-1B, a phosphatase that inhibits the insulin receptor tyrosine kinase activity.

\section{Clinician's Corner}

- Genetic susceptibility, environmental factors, microbial flora, and alterations affecting both the innate and adaptive immune systems are common components that are emphasised as major contributors to the complex set of inflammatory bowel diseases (IBDs). Most 
importantly, the cytokine imbalance of pro-inflammatory and favourable regulating cytokine responses is thought to be critically involved. The current strategies consider these elements and some immunosuppressive drugs, corticoids and biologics have shown efficacy in reducing, at least transiently, the disease progression.

- Some of the current drugs display harmful effects that can generate even more dramatic health status. Thus, deciphering further the molecular and cellular elements giving rise to IBDs is necessary.

1129

- The objective of novel therapeutic strategies is to replace disease-modifying medications by mechanism-driven therapies, which will be much more targeted and specific than the current ones and should therefore prove to be safer for the patients. Such targeted therapies could be personalised if appropriate biomarkers of responsiveness can be identified, avoiding thus the use of medications that are ineffective in individual patients.

- Due to the diversity of symptoms in IBDs, and the extent and location of inflammation, it is unlikely that a single drug will correct all the defaults in the millions of patients affected by CD and UC. Combination therapy, or polytherapy, should help to control these aspects. In these cases, however, a particular caution should be taken to avoid administration of selective molecules with opposite properties that can adversely occur in certain individuals. 
1143 HCQ (hydroxylated analogue of chloroquine): this potent autophagy inhibitor prevents 1144 lysosomal acidification, thereby interfering with a key step in the autophagic process. Also 1145 acts as a TLR7/9 inhibitor.

1146 IRGM: belongs to the p47 immunity-related GTPase family. Is implicated in autophagy 1147 induction and autophagosome maturation. Reduced expression of IRGM increases the 1148 survival of the CD-associated adherent-invasive E. coli strain, correlated with decreased 1149 autophagy-mediated bacterial clearance. Multiple CD-associated polymorphisms have been 1150 found in the IRGM locus affecting the protein expression and splicing. A CD-associated 1151 exonic synonymous single nucleotide polymorphism alters the binding of microRNA-196 to 1152 the IRGM risk variant. MicroRNA-196 is overexpressed in inflamed intestinal tissue 1153 resulting in the loss of regulation of IRGM expression levels and hence defective autophagymediated clearance of adherent-invasive E. coli bacteria.

1155 LRRK2: a multifunctional kinase localising to endolysosomal compartments and specific 1156 membrane microdomains. Is thought to be a regulator of macroautophagy and CMA. Its 1157 expression level is higher in colon biopsy specimens of patients with CD.

1158 NOD2/CARD15: an intracellular pattern-recognition protein expressed in intestinal Paneth 1159 cells and monocyte-derived immune cells. Around one-third of patients with CD harbour 1160 NOD2 mutation with a 17-fold increased risk of the disease. Three mutations within the 1161 leucine-rich repeat region have been associated with CD. Acts as a muramyl peptide sensor, 1162 which activates the NF-kB pathway in response to bacterial infections. Interacts with 1163 ATG16L1 to induce an autophagic response against bacteria. Its stimulation leads to 1164 autophagy-dependent upregulation of MHCII molecules and generation of antigen-specific $\mathrm{CD}^{+} \mathrm{T}$ cell responses.

1166 Tregs: a subset of $\mathrm{CD}^{+}$Th cells that expres the transcription factor Foxp3 and potently 1167 suppress many immune responses. 


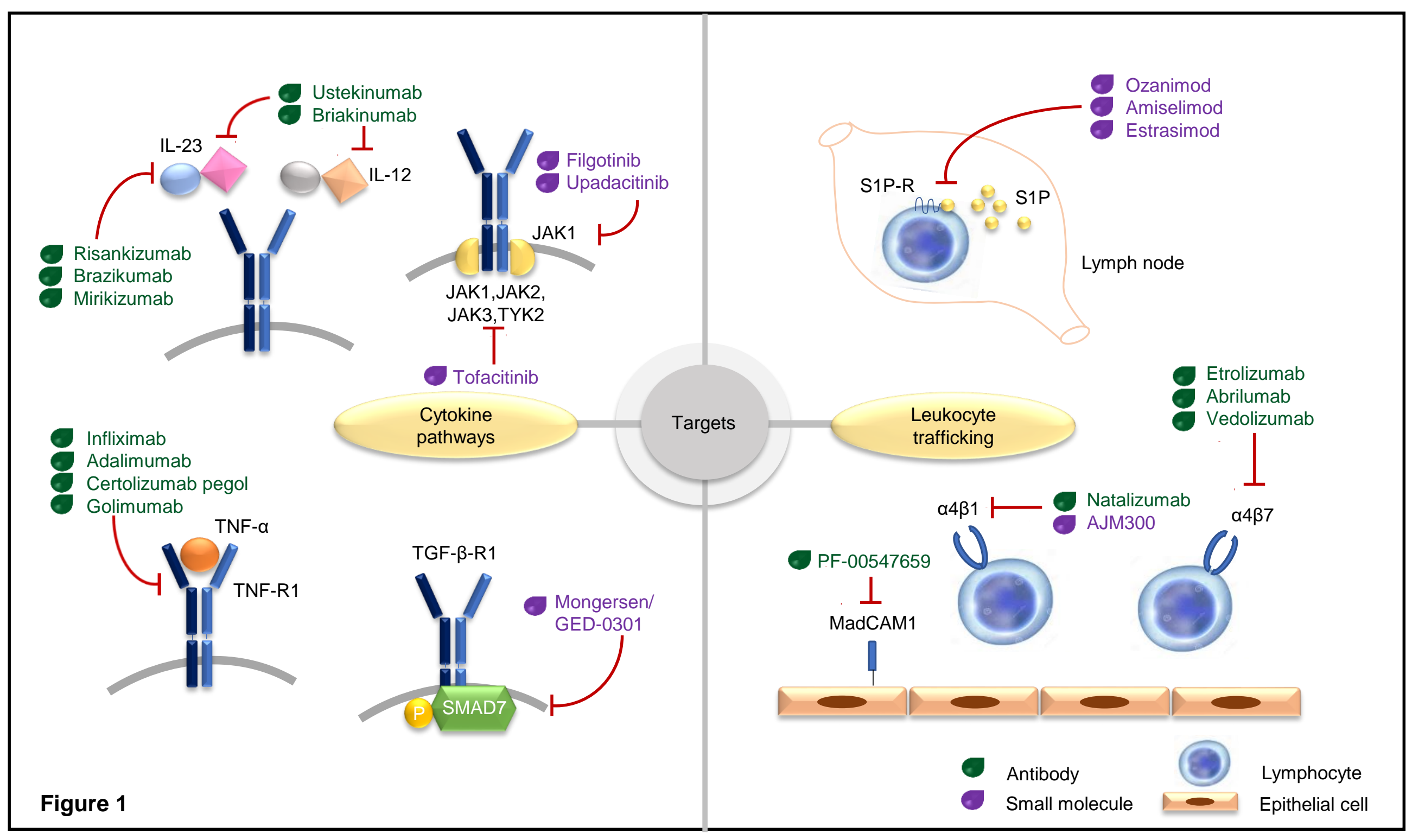




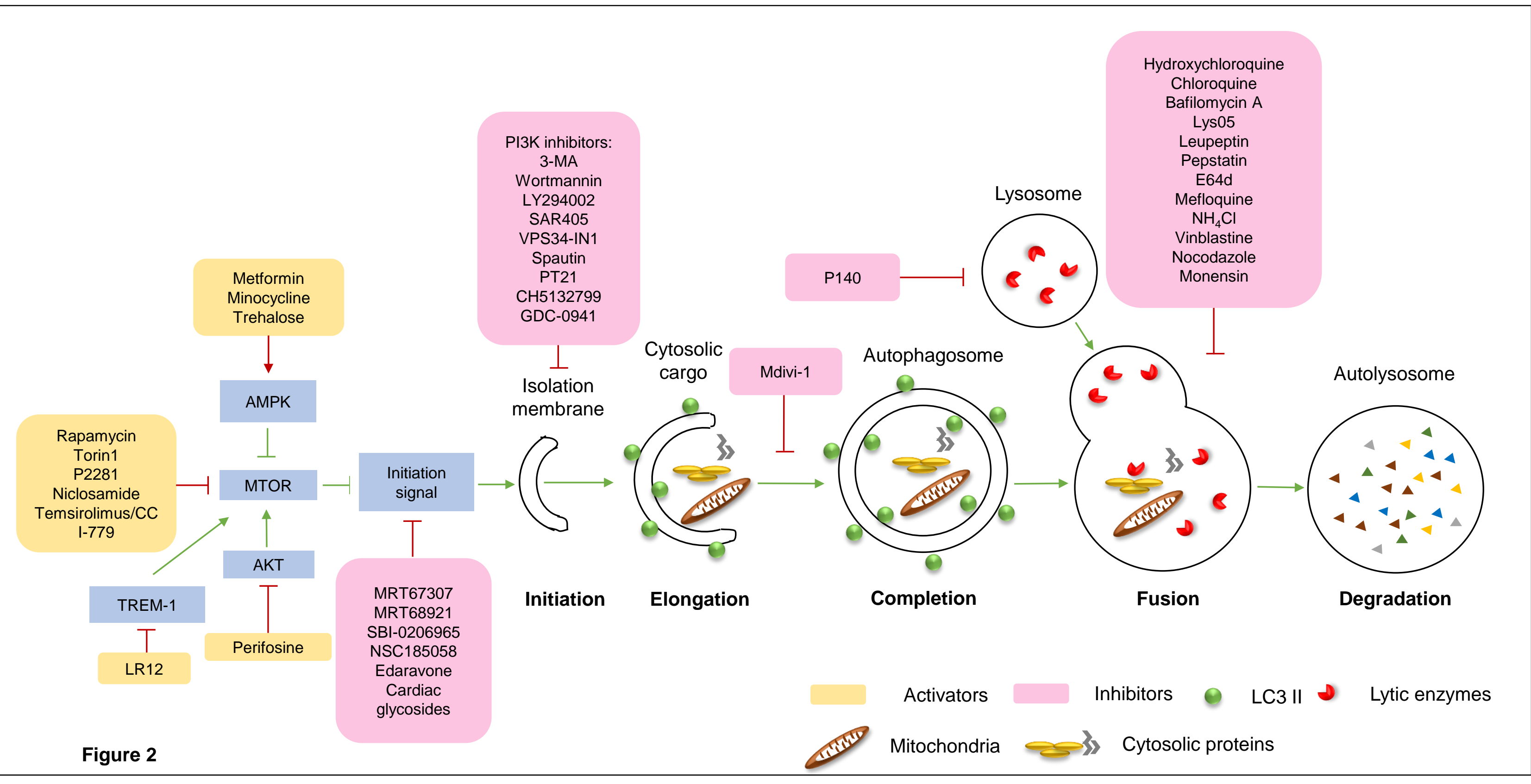




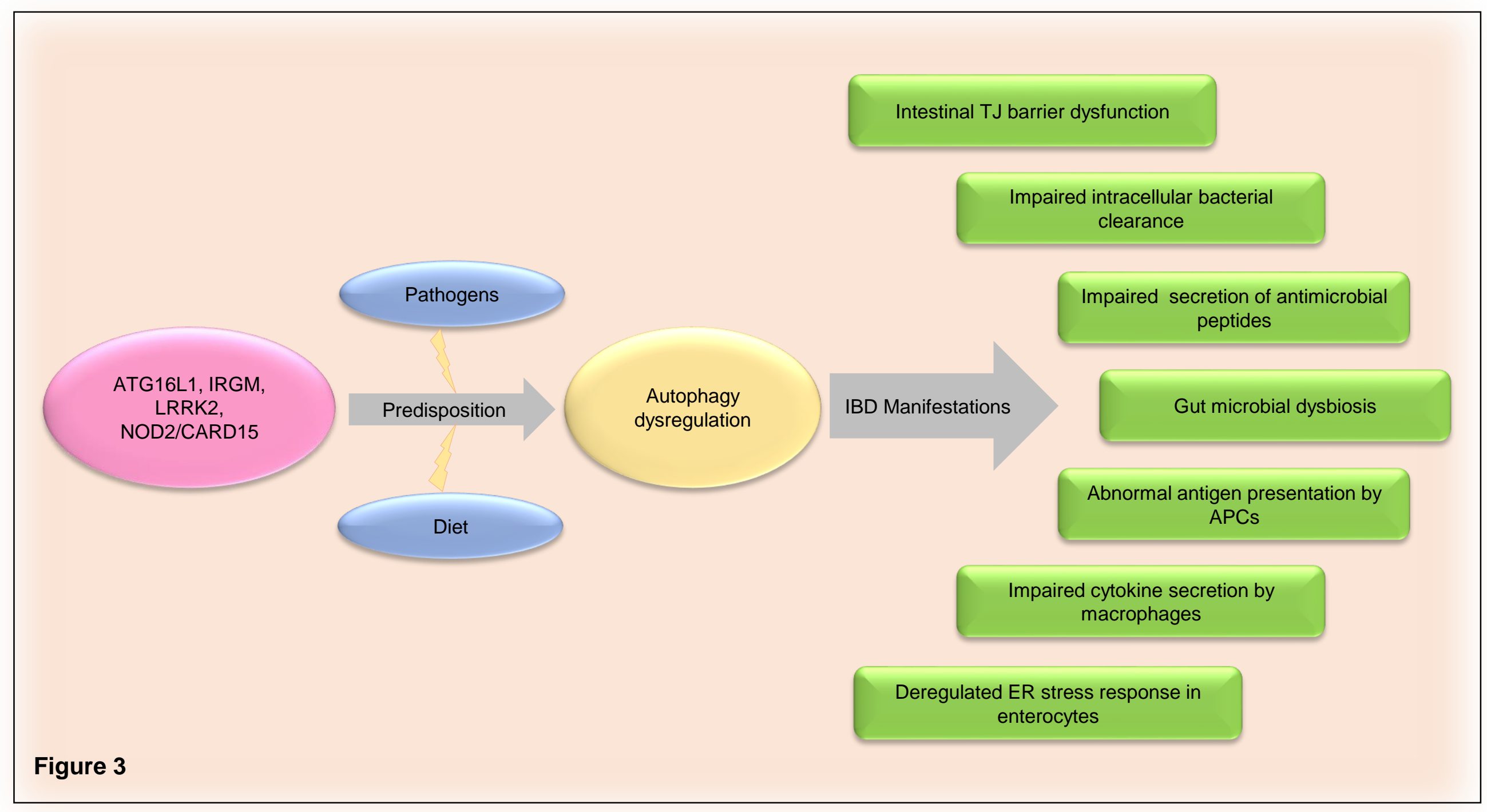

